\title{
Dissolved organic nutrients at the interface of fresh and marine waters: flow regime changes, biogeochemical cascades and picocyanobacterial blooms-the example of Florida Bay, USA
}

\author{
Patricia M. Glibert $($ ID - Cynthia A. Heil - Christopher J. Madden • \\ Stephen P. Kelly
}

Received: 15 July 2020/Accepted: 22 January 2021

(C) The Author(s) 2021

\begin{abstract}
The availability of dissolved inorganic and organic nutrients and their transformations along the fresh to marine continuum are being modified by various natural and anthropogenic activities and climate-related changes. Subtropical central and eastern Florida Bay, located at the southern end of the Florida peninsula, is classically considered to have inorganic nutrient conditions that are in higher-thanRedfield ratio proportions, and high levels of organic and chemically-reduced forms of nitrogen. However, salinity, $\mathrm{pH}$ and nutrients, both organic and inorganic, change with changes in freshwater flows to the bay. Here, using a time series of water quality and physicochemical conditions from 2009 to 2019, the impacts of distinct changes in managed flow, drought, El Niñorelated increases in precipitation, and intensive storms
\end{abstract}

Responsible Editor: Penny Johnes.

P. M. Glibert $(\bowtie)$

Horn Point Laboratory, University of Maryland Center for Environmental Science, P.O. Box 775, Cambridge, MD 21613, USA

e-mail: glibert@umces.edu

C. A. Heil

Mote Marine Laboratory, 1600 Ken Thompson Parkway, Sarasota, Fl 34236, USA

\section{J. Madden - S. P. Kelly}

South Florida Water Management District, Everglades Systems Assessment Section, 8894 Belvedere Rd,

West Palm Beach, FL 33411, USA and hurricanes are explored with respect to changes in water quality and resulting ecosystem effects, with a focus on understanding why picocyanobacterial blooms formed when they did. Drought produced hyper-salinity conditions that were associated with a seagrass die-off. Years later, increases in precipitation resulting from intensive storms and a hurricane were associated with high loads of organic nutrients, and declines in $\mathrm{pH}$, likely due to high organic acid input and decaying organic matter, collectively leading to physiologically favorable conditions for growth of the picocyanobacterium, Synechococcus spp. These conditions, including very high concentrations of $\mathrm{NH}_{4}{ }^{+}$, were likely inhibiting for seagrass recovery and for growth of competing phytoplankton or their grazers. Given projected future climate conditions, and anticipated cycles of drought and intensive storms, the likelihood of future seagrass die-offs and picocyanobacterial blooms is high.

Keywords Dissolved organic matter - Organic nutrients $\cdot$ Ammonium $\cdot \mathrm{pH} \cdot$ Humic acids . Hypersalinity · Picocyanobacteria $\cdot$ El Niño . Hurricanes

\section{Introduction}

River discharge and freshwater flow have long been recognized as major determinants of estuarine health 
(e.g., Montagne et al. 2012) through the delivery of fresh water as well as the nutrients dissolved within (e.g., Ye et al. 2012; Beusen et al. 2016; Massotti et al. 2018). River discharge is changing in many parts of the world, from physical manipulations such as dam construction (e.g., Grill et al. 2015; Zarfl et al. 2015), channelization or management-regulated flow (e.g., Madden 2010), and from climate change (VicenteSerrano et al. 2019; Glibert 2020, Glibert et al. 2020), which is leading to large-scale changes in precipitation (Easterling et al. 2000). Different regions-and even the same regions at different times-are experiencing increased frequency of droughts and/or storms, both of which can alter the amount and forms of nutrient delivery to aquatic systems (O'Neil et al. 2012; Glibert et al. 2018, 2020 and references therein). During droughts, land-based nutrients accumulate, increasing potential for nutrient runoff when flow becomes reestablished (Glibert 2020). Droughts also change the potential for retention of nutrients within receiving waters, altering their propensity to be recycled or transformed. With warming of the oceans, storms, when they do occur, are becoming stronger and "wetter", as warmer waters serve as the accelerant for such storms and a warmer atmosphere holds more moisture (Easterling et al. 2000; Knutson and Tuleya 2004). Storms can also change hydrologic flow path, increasing passage through litter and upper soil horizons (e.g., Hornberger et al. 1994; Hagedorn et al. 2000). Storms thus not only increase total runoff, but also organic matter delivery. The biogeochemical and biological changes occurring as freshwater flow and its associated nutrients change against a backdrop of warmer waters are just beginning to be understood.

Changing nutrient loads-both inorganic and organic-are also a function of changes in coastal land use and development, as well as specific management actions designed to modify the flow of water or nutrients to receiving water bodies (e.g., Howarth 2008; Seitzinger et al. 2010; Beusen et al. 2016; Shangguan et al. 2017a,b; Glibert et al. 2014, 2018). The temporal and spatial scales of such changes is exceptionally pronounced in South Florida. From the first flux of people to the area following the completion of Florida East Coast Railway linking the Florida Keys in 1912, to the large shift in sugar agriculture from Cuba to South Florida in 1959 following the Cuban revolution, to more recent extensive coastal residential development, change has been a constant characteristic of the south Florida coastal environment (Hollander 2008). Throughout the twentieth century, the hydrology, water budget and flow regime of South Florida have been significantly altered by engineered channelization of water flow away from historic flow paths across the bay's northern boundary (Madden 2010; Marshall et al. 2020). This has historically led to reductions in the natural flow to Florida Bay, which, combined with episodic droughts, have led to associated ecological degradation. The related stresses of low freshwater flow-with resulting increased salinity, combined with chemically complex and changing nutrient loads, have been associated with episodic, as well as prolonged, seagrass losses and persistent picocyanobacterial blooms (Synechococcus spp.) that now threaten the ecological health of Florida Bay (e.g., Phlips and Babylak 1996, Hitchcock et al. 1998, Phlips et al. 1999; Glibert et al. 2004, 2009, 2010).

A significant result of climate change is increases in the frequency and magnitude of harmful cyanobacterial blooms in many freshwater systems (O'Neil et al., 2012; Paerl and Huisman 2009; Paerl and Paul 2012). Beyond the hydrological and chemical changes that both accompany, and result from, natural and manmade alterations in flow regimes, there is also potential for an increase in the transport of harmful algal blooms (HABs) between freshwater and marine systems with altered flow. Transport of these blooms and their toxins from fresh water to brackish and marine environments, where increases in salinity result in cyanobacterial cell death and subsequent nutrient and toxin release, is being increasingly recognized as a global threat to environmental and human health (Preece et al. 2017). Indeed, Lake Okeechobee, which historically fed the headwaters of the Everglades, has experienced increasing occurrences of toxic Microcystis blooms in recent years (Phlips et al. 2020). In 2018, a high biomass, spatially extensive Lake Okeechobee Microcystis bloom was released from the Lake to the St. Lucie and Caloosahatchee River estuaries through management actions implemented to lower Lake levels for flood prevention. Microcystis has been shown to grown in salinities up to 10 (reviewed by Preece et al 2017) and survive in salinities up to 17.5 (Tonk et al. 2007), so the riverine transport of these blooms-and their ultimate decomposition-represents an additional nutrient input resulting from altered flow regimes. 
To enhance flow and to reverse the stress of low freshwater input, the first phases of one of the largest and most complex flow restoration projects in the world have been implemented, the Comprehensive Everglades Restoration Plan (CERP, https:www.nps. gov/ever/learn/nature/upload/CERPFSLoResSecure. pdf). This joint state and federal project, with a cost of billions of dollars and a multidecadal time scale, is intended to improve the amount, timing and distribution of freshwater flow to Florida Bay. Yet, with this change in flow, the amounts and forms of nutrients are also altered (Shangguan et al. 2017a,b). The relationship between downstream blooms and the nutrient load of Florida Bay, both inorganic and organic, originating from the Everglades watershed has been the topic of much scientific and managerial debate (e.g., Lapointe and Clark 1992; Boesch et al. 1993; Zieman et al. 1999; Phlips et al. 1999; Lapointe and Barile 2004; Glibert et al. 2004; Lapointe et al. 2019, 2020, Julian 2020).

Identifying and understanding the processes underlying these complex systems requires long-term data sets of multiple variables that span periods of change. Long-term data are needed not just to understand the processes driving the system, but many of the impacts which can be displaced in time or space from the environmental driver. In the years from 2009 to 2019 , a number of distinct, sequential, hydrological events occurred in the Florida Bay watershed that led to altered water quality, but in different ways. During these varying periods of hydrological change, temporally displaced seagrass die-offs and picocyanobacterial blooms occurred. These hydrological events allowed for individual factors to be examined with respect to these die-offs and blooms and the causative downstream biogeochemical and physiological mechanisms and their timing. This paper thus addresses the questions: How did water quality change with managed flow, drought, El Niño events, and storm events? How were these changes, individually and collectively, related to seagrasses losses and picocyanobacterial blooms in Florida Bay, both biogeochemically and physiologically? Of particular interest was the extent to which organic loads changed in each of the hydrologic periods and how that affected water quality and biogeochemistry, as well as the sequence of events and their interactions that contributed to sustained picocyanobacterial blooms that occurred only late in the time series. Organic loads are hypothesized to not only directly provide substrate for algal blooms, but to indirectly increase the availability of inorganic nutrients through biogeochemical interactions. An integrated approach to the management of this system requires both an understanding of the important stressors in the system and their interdependence as well as knowledge of the behavior of these stressors under different hydrological regimes.

\section{Methods}

Site description

Florida Bay is approximately $2200 \mathrm{~km}^{2}$ in area and directly connects to the Everglades wetland system at its northern boundary (Fig. 1a). It is shallow, with an average depth of approximately $1.5 \mathrm{~m}$, and typically unstratified. The bay has an extensive series of small linked basins which restrict water movement. The bay typically has two distinct meteorological seasons: a November-April dry season and a May-October rainy season that encompasses Florida's hurricane season and during which $75 \%$ of annual precipitation typically occurs (Duever et al. 1994).

The eastern, northern and central regions of Florida Bay have long water residence times, on the order of 4-12 mo (Lee et al. 2006, 2008), low tidal influence and comparatively low direct freshwater inflow. Indeed, flows can at time be negative, during which water may flow from the bay into the Everglades transitional zone. This occurs primarily in the dry season when prevailing winds become a dominant factor in water movement. Without major rivers draining into this estuary, the freshwater input to Florida Bay is largely via slowly flowing surface fresh water from the Everglades that traverses wetlands and mangroves via Taylor and Shark River Sloughs (Lee et al. 2007).

In north-central Florida Bay, the freshwater flow path is through a series of interconnected saline 'lakes', or quasi-intermittent closed-open lakes-lagoons (ICOLLS; Fig. 1a). There are two such interconnected sets of ICOLLS, relatively isolated from each other, with each exhibiting distinctive geological and ecological characteristics (Frankovich et al. 2011, Shangguan et al. 2017a). Both sets of ICOLLS receive fresh water mainly from Taylor Slough, flow from which gradually widens as it extends south, ultimately 

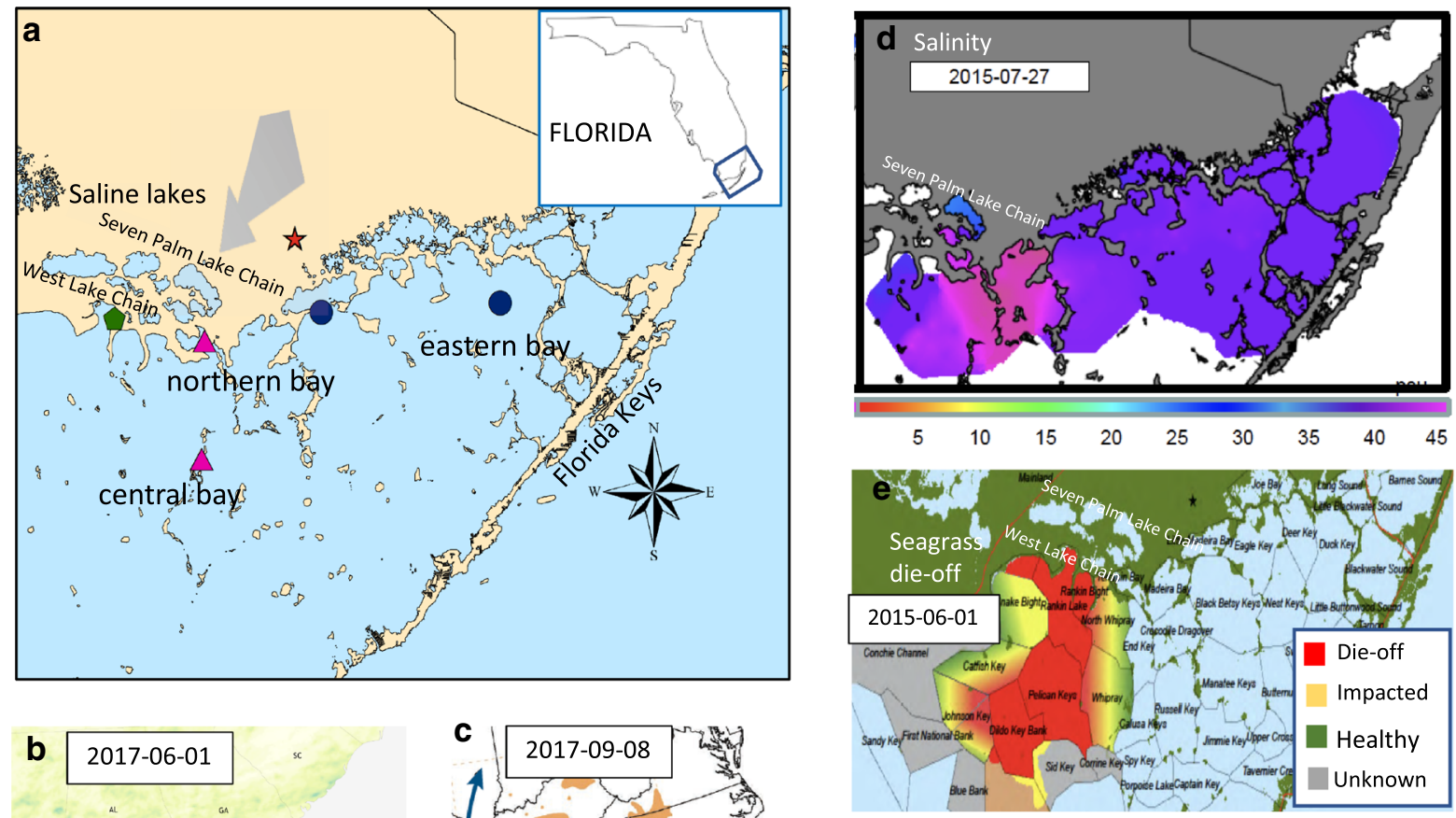
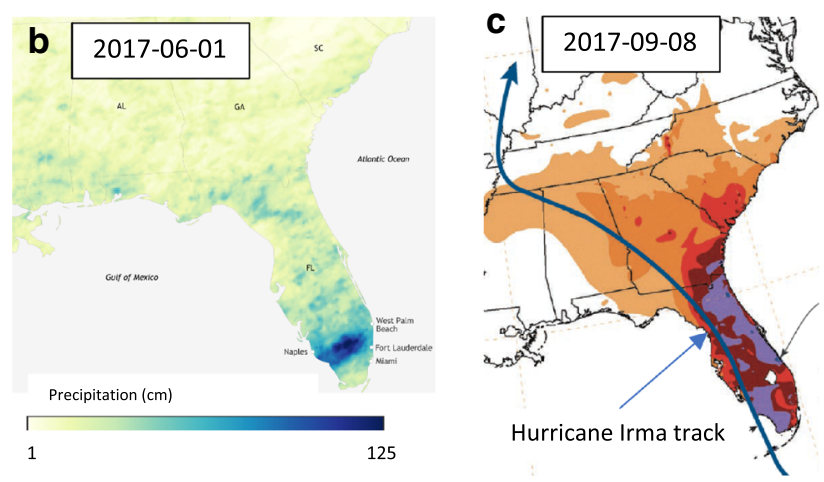

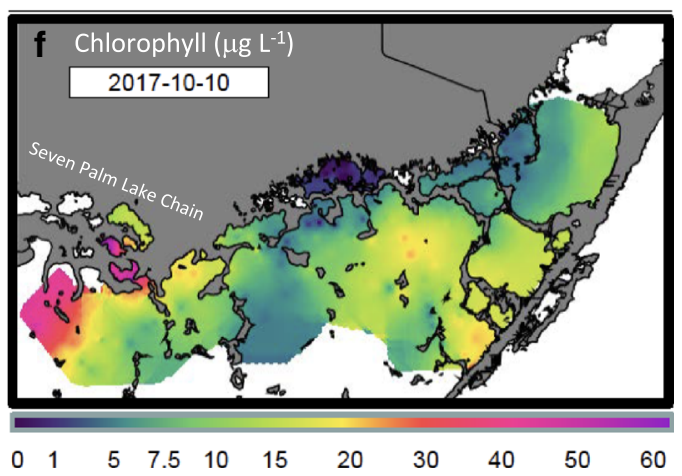

Hurricane Irma and region of most intense precipitation. d Surface map of salinity in eastern and central bay in July 2015. e Region of seagrass die-off in June 2015, provided courtesy of C. Kavanagh, Everglades National Park. f Surface map of chlorophyll $a$ in eastern and central bay in October 2017

phytoplankton bioreactors, and with increasing flow there is the potential to transport elevated phytoplankton biomass from these lakes to the receiving water body.

In the years from 2009 to 2019, a number of distinct events occurred that altered flow, nutrient delivery, and biogeochemical processing, altering habitat for seagrass and phytoplankton. There were 3 El Niño events, two of which were comparatively small, in late 2009 and 2019, while in late 2015, one of the strongest 
El Niño events in decades developed which lasted into mid-2016. El Niño events typically lead to cooler and stormier winters in South Florida. In mid-2012, the first phase of implementation of the CERP C-111 project restoration plan began, the $\mathrm{C} 111$ Spreader Canal Western Feature Project (C111SC), increasing flow into Taylor Slough via improved seepage management in the canal system and structural changes that increased flow into the Everglades. South Florida also experienced an unusually prolonged regional drought, lasting over a year from 2014 to mid 2015, which resulted in very low flows. Conditions changed again in summer 2017 when a very intense, but localized, unnamed storm in June, and other tropical storms, including Hurricane Irma in September, brought high levels of precipitation to the region (Fig. 1b,c). In all, these events led to a period of hypersalinity in 2015 (Fig. 1d) which was coincident with seagrass die-offs (Fig. 1e), and two years later-in 2017-sustained picocyanobacterial blooms developed when hydrological conditions changed (Fig. 1f). Here, time series water quality data from 2009 to 2019 are brought to bear to describe the changes in the amount, composition and transport of organic and inorganic nutrients and other water quality parameters and to place these changes in context with the physiological responses and biogeochemical changes that link flow conditions to both seagrass die-offs and to the extensive picocyanobacterial blooms in Florida Bay that occurred several years later.

\section{Data sets}

Since 1989, water quality parameters, including chlorophyll $a(\mathrm{Chl} a$ ), inorganic and total (organic) nutrients, turbidity and hydrographic parameters (temperature, salinity, $\mathrm{pH}$ ), have been monitored monthly or bimonthly at up to 28 stations in Florida Bay-the Florida Bay Water Quality Monitoring Network-following established protocols of the South Florida Water Management District (SFWMD 2015a, b). Supplementing individual station data are data acquired from water quality mapping from a small boat, using the DataFlow mapping system (Madden and Day 1992). The analysis herein focuses on the 11-year record from 2009 to 2019, the period of most recent changes in managed flow, drought, and extreme precipitation. Changes experienced at the 4 stations in the central bay that have experienced the most intensive seagrass die-offs and picocyanobacterial blooms during this time period are analyzed.

Discharge data were obtained from US Geological Survey site 251032080473400 measured at Alligator Creek near Garfield Bight (www.waterdata.usgs.gov). Precipitation data were downloaded from the Everglades Depth Estimation Network (EDEN) database through the Explore and View EDEN (EVE) web application (www.sofia.usgs.gov/eden).

The Oceanic Niño Index (ONI), as reported by the US National Oceanic and Atmospheric Administration (www.climate.gov) is a measure of the 3-month average of sea surface temperature in the east-central tropical Pacific, and as such is an indicator of El Niño and La Niña conditions. El Niño conditions are present, according to this index, when the ONI is 0.5 or greater.

\section{Data analyses}

The data for the time series are presented as time courses of the monthly or bimonthly data from the central bay, averaging the 4 stations routinely sampled. Several types of averages are reported. For the time courses, monthly data for each year, averaged for the 4 central bay stations, are compared to the monthly average of the 11-year time series and \pm 1 standard deviation of that average value. The data were also averaged by year for 5 individual water years (WY) to highlight the differences between the pre- and postCERP conditions, drought, El Niño and post-hurricane periods (note that for $\mathrm{pH}$, all averages are true averages not arithmetic averages). By convention, a WY runs from May 1 to the following April 30 to encompass a full and complete wet and dry season. The maximum individual values recorded for each parameter during that specific year are also reported. Changes in water quality parameters in these periods were compared by ANOVA, followed by Tukey's HSD tests for pairwise comparisons. Regression analysis was also used to compare various environmental parameters over the time course. 


\section{Results}

Physical drivers: rainfall, flow, salinity, temperature and $\mathrm{pH}$

Rainfall (time series begins in January 2010) exhibits a typical pattern of highs, typically reaching $0.80-1.00 \mathrm{~cm}$ per month during the wet season, and little or no rainfall during the dry season (Fig. 2a). During the drought years of 2014-2015, rainfall only increased towards the end of what is normally considered the wet season and was sustained well into what is normally considered the dry season (Fig. 2a). The wet season of 2019 was also atypical, with low rainfall, about half of normal. Exceptionally high rainfall, reaching $1.80 \mathrm{~cm}$ per month, was observed during the wet season of 2017, when multiple storms, including Hurricane Irma, occurred.
Flow tends to lag rainfall, rising from about July, and typically peaking at the beginning of the nominal dry season (October), and remaining high until the early months of the calendar year (Fig. 2b). In 2015, however, positive flows were not seen for much of what would normally be the late wet season, while the normal dry season witnessed sustained high flows. The ONI reflected $3 \mathrm{El}$ Niño events, increasing to 1.5 in late 2009 , from $\sim 0.6$ early in 2015 to a high of 2.5 late in 2015, indicating strong El Niño conditions, and comparatively weak El Niño conditions in late 2018, when the ONI approached 1.0 (Fig. 2b).

In the pre- and post-C11SC project time period, average monthly salinity at the 4 central bay stations oscillated between lows of $<30$ to highs of $>50$ (Fig. 3a). Highest salinity is typically seen at the end of the dry season. The very low salinities of winter 2010 followed the first El Niño of the time series,
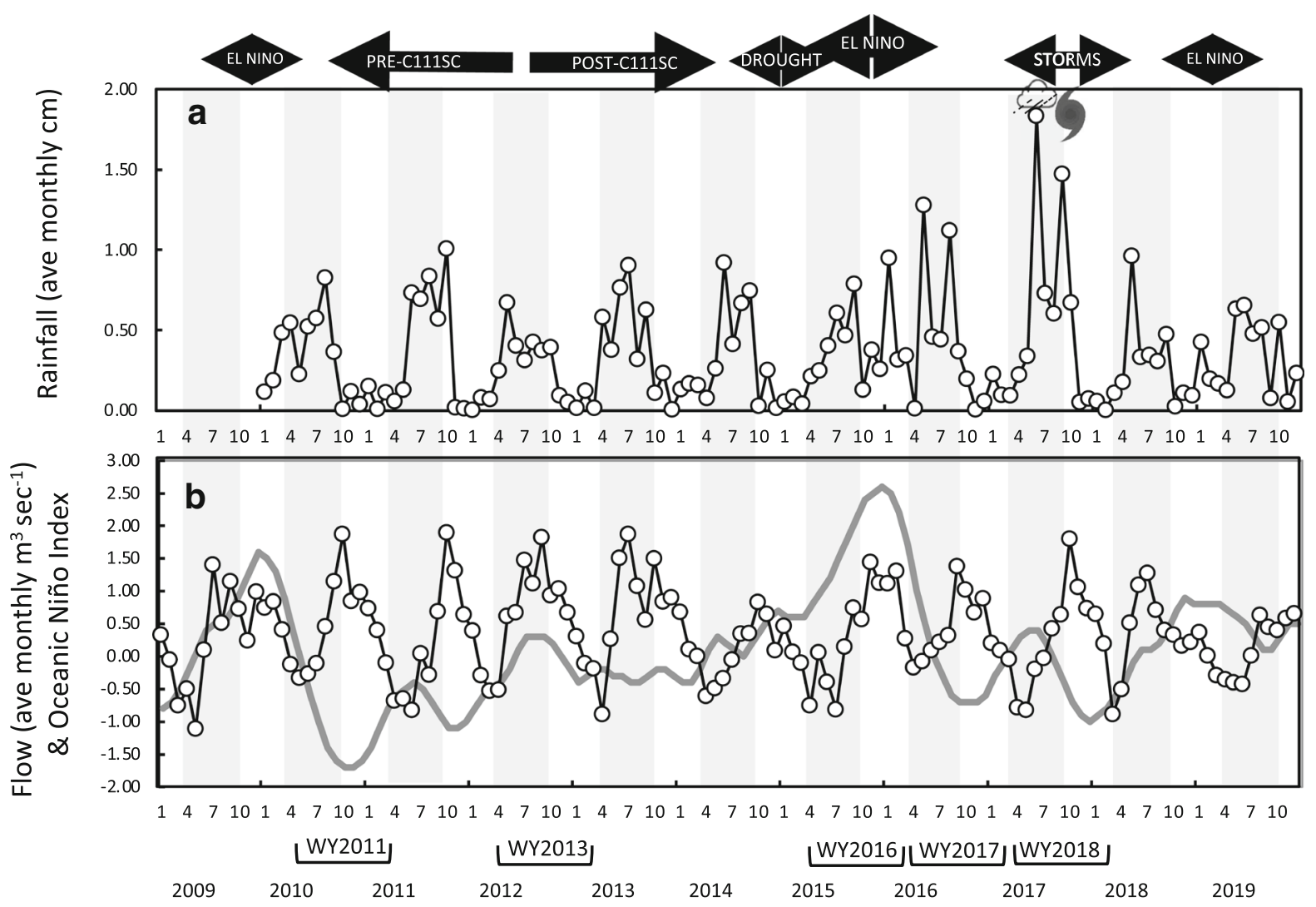

Fig. 2 Time series of a rainfall from 2010 to 2019 and b flow from US Geological Survey site 251032080473400 measured at Alligator Creek near Garfield Bight (individual data points) and Oceanic Niño Index (superimposed gray line). Key time points discussed in text, including implementation of CC11SC, drought, El Niño and storm events are indicated above the panels, and water years summarized in Table 1 are indicated below the panels. The alternating light and dark vertical bands show the classically considered wet (gray bars) and dry (clear bars) seasons 
Table 1 Average ( \pm standard deviation) of parameters indicated for 5 distinct water years (WY) representing 5 conditions in Florida Bay as described in text.I

\begin{tabular}{|c|c|c|c|c|c|}
\hline $\begin{array}{l}\text { Period } \\
\text { Parameter }\end{array}$ & $\begin{array}{l}\text { Pre-CERP } \\
\text { WY } 2011\end{array}$ & $\begin{array}{l}\text { Post-CERP } \\
\text { WY } 2013\end{array}$ & $\begin{array}{l}\text { Post Drought } \\
\text { WY } 2016\end{array}$ & $\begin{array}{l}\text { Post El Niño } \\
\text { WY2017 }\end{array}$ & $\begin{array}{l}\text { Storms } \\
\text { WY2018 }\end{array}$ \\
\hline $\begin{array}{l}\text { Flow } \\
\left(\mathrm{m}^{3} \mathrm{sec}^{-1}\right)\end{array}$ & $\begin{array}{l}0.25 \pm 0.62^{a} \\
(1.84)\end{array}$ & $\begin{array}{l}-0.02 \pm 0.64^{a} \\
(1.28)\end{array}$ & $\begin{array}{l}0.11 \pm 0.57^{a} \\
(1.27)\end{array}$ & $\begin{array}{l}0.31 \pm 0.58^{a} \\
(1.35)\end{array}$ & $\begin{array}{l}0.02 \pm 0.60^{a} \\
(1.03)\end{array}$ \\
\hline $\begin{array}{l}\text { Rainfall } \\
(\mathrm{cm})\end{array}$ & $\begin{array}{l}0.25 \pm 0.26^{a} \\
(0.82)\end{array}$ & $\begin{array}{l}0.26 \pm 0.20^{a} \\
(0.67)\end{array}$ & $\begin{array}{l}0.42 \pm 0.24^{a} \\
(0.95)\end{array}$ & $\begin{array}{l}0.38 \pm 0.42^{a} \\
(1.28)\end{array}$ & $\begin{array}{l}0.51 \pm 0.60^{a} \\
(1.83)\end{array}$ \\
\hline $\begin{array}{l}\text { Temperature } \\
\left({ }^{\circ} \mathrm{C}\right)\end{array}$ & $\begin{array}{l}25.56 \pm 5.81^{a} \\
(34.30)\end{array}$ & $\begin{array}{l}27.15 \pm 3.58^{a} \\
(32.40)\end{array}$ & $\begin{array}{l}25.90 \pm 5.99^{a} \\
(33.90)\end{array}$ & $\begin{array}{l}26.70 \pm 3.55^{a} \\
(31.50)\end{array}$ & $\begin{array}{l}26.16 \pm 4.69^{a} \\
(32.40)\end{array}$ \\
\hline Salinity & $\begin{array}{l}34.90 \pm 5.98^{a} \\
(44.90)\end{array}$ & $\begin{array}{l}33.04 \pm 3.58^{a} \\
(40.60)\end{array}$ & $\begin{array}{l}40.43 \pm 8.51^{b} \\
(56.50)\end{array}$ & $\begin{array}{l}36.50 \pm 3.59^{a} \\
(40.90)\end{array}$ & $\begin{array}{l}33.70 \pm 7.02^{a} \\
(44.40)\end{array}$ \\
\hline $\mathrm{pH}$ & $\begin{array}{l}8.47 \pm 0.23^{a} \\
(9.00)\end{array}$ & $\begin{array}{l}8.31 \pm 0.17^{a} \\
(8.80)\end{array}$ & $\begin{array}{l}8.10 \pm 0.36^{b} \\
(8.90)\end{array}$ & $\begin{array}{l}8.10 \pm 0.16^{b} \\
(8.40)\end{array}$ & $\begin{array}{l}7.85 \pm 0.28^{c} \\
(8.60)\end{array}$ \\
\hline $\begin{array}{l}\text { Turbidity } \\
\text { (NTU) }\end{array}$ & $\begin{array}{l}1.90 \pm 1.29^{a} \\
(8.80)\end{array}$ & $\begin{array}{l}2.75 \pm 1.47^{a} \\
(6.20)\end{array}$ & $\begin{array}{l}2.10 \pm 1.16^{a} \\
(4.80)\end{array}$ & $\begin{array}{l}3.54 \pm 2.54^{a} \\
(10.30)\end{array}$ & $\begin{array}{l}8.27 \pm 8.86^{b} \\
(51.40)\end{array}$ \\
\hline $\begin{array}{l}\text { DO } \\
\left(\mathrm{mg} \mathrm{L}^{-1}\right)\end{array}$ & $\begin{array}{l}7.19 \pm 1.09^{a} \\
(9.38)\end{array}$ & $\begin{array}{l}5.18 \pm 1.44^{b} \\
(7.98)\end{array}$ & $\begin{array}{l}6.29 \pm 1.85^{a} \\
(9.47)\end{array}$ & $\begin{array}{l}5.86 \pm 1.19^{b} \\
(8.06)\end{array}$ & $\begin{array}{l}5.78 \pm 2.26^{b} \\
(8.93)\end{array}$ \\
\hline $\begin{array}{l}\mathrm{NO}_{3}^{-} \\
(\mu \mathrm{M}-\mathrm{N})\end{array}$ & $\begin{array}{l}0.20 \pm 0.06^{a} \\
(0.05)\end{array}$ & $\begin{array}{l}0.18 \pm 0.00^{a} \\
(0.18)\end{array}$ & $\begin{array}{l}0.42 \pm 0.43^{b} \\
(1.57)\end{array}$ & $\begin{array}{l}0.20 \pm 0.11^{a} \\
(0.86)\end{array}$ & $\begin{array}{l}0.24 \pm 0.14^{a} \\
(0.79)\end{array}$ \\
\hline $\begin{array}{l}\mathrm{NH}_{4}^{+} \\
(\mu \mathrm{M}-\mathrm{N})\end{array}$ & $\begin{array}{l}2.27 \pm 1.53^{a} \\
(7.57)\end{array}$ & $\begin{array}{l}2.21 \pm 2.19^{a} \\
(9.99)\end{array}$ & $\begin{array}{l}15.94 \pm 20.91^{b} \\
(80.09)\end{array}$ & $\begin{array}{l}3.74 \pm 3.25^{a} \\
(14.85)\end{array}$ & $\begin{array}{l}7.32 \pm 8.36^{c} \\
(44.75)\end{array}$ \\
\hline $\begin{array}{l}\mathrm{PO}_{4}{ }^{3-} \\
(\mu \mathrm{M}-\mathrm{P})\end{array}$ & $\begin{array}{l}0.05 \pm 0.03^{a} \\
(0.13)\end{array}$ & $\begin{array}{l}0.04 \pm 0.02^{a} \\
(0.10)\end{array}$ & $\begin{array}{l}0.05 \pm 0.03^{a} \\
(0.16)\end{array}$ & $\begin{array}{l}0.03 \pm 0.00^{b} \\
(0.06)\end{array}$ & $\begin{array}{l}0.03 \pm 0.00^{b} \\
(0.03)\end{array}$ \\
\hline $\begin{array}{l}\text { DIN/DIP } \\
\text { (molar) }\end{array}$ & $\begin{array}{l}58 \pm 44^{a} \\
(245)\end{array}$ & $\begin{array}{l}63 \pm 64^{a} \\
(315)\end{array}$ & $\begin{array}{l}418 \pm 577^{b} \\
(2485)\end{array}$ & $\begin{array}{l}121 \pm 103^{a, c} \\
(465)\end{array}$ & $\begin{array}{l}234 \pm 260^{c} \\
(1392)\end{array}$ \\
\hline $\begin{array}{l}\text { DON } \\
(\mu \mathrm{M}-\mathrm{N})\end{array}$ & $\begin{array}{l}78 \pm 17^{a} \\
(115)\end{array}$ & $\begin{array}{l}83 \pm 14^{a} \\
(115)\end{array}$ & $\begin{array}{l}87 \pm 25^{a} \\
(133)\end{array}$ & $\begin{array}{l}94 \pm 32^{b} \\
(166)\end{array}$ & $\begin{array}{l}101 \pm 33^{b} \\
(190)\end{array}$ \\
\hline $\begin{array}{l}\text { DOP } \\
(\mu \mathrm{M}-\mathrm{P})\end{array}$ & $\begin{array}{l}0.28 \pm 0.09^{a} \\
(0.52)\end{array}$ & $\begin{array}{l}0.37 \pm 0.13^{a, b} \\
(0.68)\end{array}$ & $\begin{array}{l}0.37 \pm 0.15^{a} \\
(0.81)\end{array}$ & $\begin{array}{l}0.56 \pm 0.42^{b} \\
(2.00)\end{array}$ & $\begin{array}{l}0.84 \pm 0.64^{c} \\
(2.58)\end{array}$ \\
\hline $\begin{array}{l}\text { DOC } \\
(\mu \mathrm{M}-\mathrm{C})\end{array}$ & $\begin{array}{l}972 \pm 179^{a} \\
(1359)\end{array}$ & $\begin{array}{l}1004 \pm 165^{a} \\
(1307)\end{array}$ & $\begin{array}{l}863 \pm 28 z^{a} \\
(1323)\end{array}$ & $\begin{array}{l}973 \pm 270^{a} \\
(1573)\end{array}$ & $\begin{array}{l}1024 \pm 259^{a} \\
(1840)\end{array}$ \\
\hline $\begin{array}{l}\text { DON/DOP } \\
\text { (molar) }\end{array}$ & $\begin{array}{l}310 \pm 120^{a} \\
(697)\end{array}$ & $\begin{array}{l}248 \pm 71^{a} \\
(407)\end{array}$ & $\begin{array}{l}266 \pm 141^{a} \\
(699)\end{array}$ & $\begin{array}{l}243 \pm 156^{a} \\
(660)\end{array}$ & $\begin{array}{l}188 \pm 135^{b} \\
(618)\end{array}$ \\
\hline $\begin{array}{l}\text { DOC/DON } \\
\text { (molar) }\end{array}$ & $\begin{array}{l}12.57 \pm 1.31^{a} \\
(16.26)\end{array}$ & $\begin{array}{l}12.21 \pm 0.95^{a} \\
(14.13)\end{array}$ & $\begin{array}{l}9.81 \pm 0.86^{b} \\
(11.18)\end{array}$ & $\begin{array}{l}10.70 \pm 2.03^{b} \\
(14.98)\end{array}$ & $\begin{array}{l}10.46 \pm 1.61^{b} \\
(13.36)\end{array}$ \\
\hline $\begin{array}{l}\text { Chlorophyll } \\
\quad a \\
\left(\mu \mathrm{g} \mathrm{L}^{-1}\right)\end{array}$ & $\begin{array}{l}0.65 \pm 0.50^{a} \\
(3.07)\end{array}$ & $\begin{array}{l}2.46 \pm 2.34^{a, b} \\
(10.50)\end{array}$ & $\begin{array}{l}1.71 \pm 1.19^{a, b} \\
(5.53)\end{array}$ & $\begin{array}{l}5.66 \pm 6.65^{b} \\
(30.00)\end{array}$ & $\begin{array}{l}10.63 \pm 11.70^{c} \\
(53.10)\end{array}$ \\
\hline
\end{tabular}

With the exception of flow and precipitation, which were derived from the sources noted in text, each of the other parameters is the average of 4 stations sampled either monthly or bimonthly for a 12-month period. All values for $\mathrm{pH}$ are true averages, not arithmetic averages. Values in parentheses represent the individual maximum value recorded in the yearly time series. By convention, water years encompass a wet and dry season, beginning with the wet season in May of the previous calendar year (e.g., WY2012 encompasses May 2011-April 2012). Letters denote significant differences at a level of at least $\mathrm{p}<0.05$ 

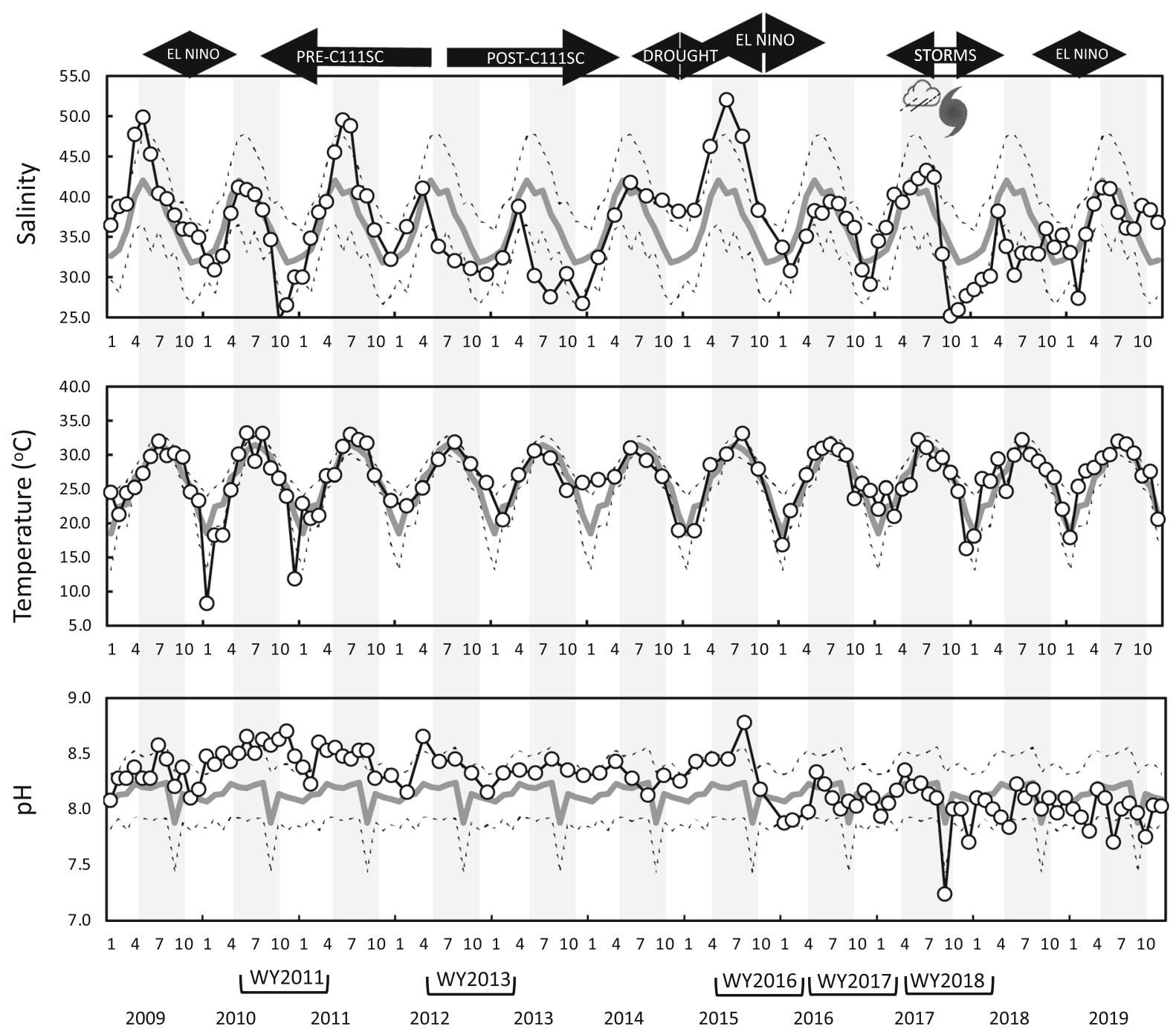

Fig. 3 Time series of a salinity, $\mathbf{b}$ temperature, and $\mathbf{c} \mathrm{pH}$ from 2009 to 2019. On each panel, the solid gray line represents the annual average for the parameter considered for the 11-year time series. The annual pattern is repeated each year for context. The dashed lines represent \pm 1 standard deviation of this average. The line with individual data points (small circles) are data averaged from monthly or bimonthly sampling of 4 stations in

typical of the winter storminess of El Niño. After implementation of C111SC in 2012, until onset of the drought, average salinities did not exceed 40. Late in the drought of 2015, average salinity exceeded 50 and these high salinities were maintained for much of what would have been the wet season in 2015 (Fig. 3a, Table 1). Salinity returned to near normal values in late 2015 as El Niño became established. Following the storms of 2017, salinities dropped to the lowest level of the time series, 25, at the end of 2017 wet central bay. Note that all averages for $\mathrm{pH}$ are true averages not arithmetic averages. Key time points discussed in text, including implementation of CC11SC, drought, El Niño and storm events are indicated above the panels, and water years summarized in Table 1 are indicated below the panels. The alternating light and dark vertical bands show the classically considered wet (gray bars) and dry (clear bars) seasons

season. Winter salinities were also low during the mild El Niño of winter 2018.

Temperatures typically range from $<20^{\circ} \mathrm{C}$ in the winter dry season to $>30{ }^{\circ} \mathrm{C}$ in the summer wet season (Fig. 3b). The lowest temperature of the time series was observed in early 2010, pre-C111SC during the first El Niño. From 2010 to 2014, annual lows increased from $<10^{\circ}$ to mid- $20^{\circ} \mathrm{C}$, but from 2015 to 2019, annual lows returned to more typical values, ranging from 18 to $20{ }^{\circ} \mathrm{C}$. No significant differences in 
water temperature were found for the distinct water years of the different flow periods (Table 1).

For the entire time series, average $\mathrm{pH}$ values hovered around values of 7.8-8.2, but significant changes were seen (Fig. 3c, Table 1). During the preand post-C111SC periods, the first El Niño and the drought periods, all $\mathrm{pH}$ values trended $\sim 1$ standard deviation above the average of the time series. Beginning in late 2015/early 2016, during the transition from the drought to the large El Niño, $\mathrm{pH}$ values began a downward trend, such that by the end of the time series in 2019, all $\mathrm{pH}$ values trended $\sim 1$ standard deviation below the long-term average.

\section{Inorganic nutrients}

Of the inorganic nutrients, the highest concentrations were consistently those of $\mathrm{NH}_{4}{ }^{+}$, although average concentrations for central bay changed significantly with the different defined periods and water years (Fig. 4a, Table 1). Throughout the period of pre- and post-C111SC, average concentrations of $\mathrm{NH}_{4}^{+}$ remained $<3 \mu \mathrm{M}$, although there were a few exceptions, including an increase to an average of $12.2 \mu \mathrm{M}$ in late 2009 during the first El Niño, and $7.3 \mu \mathrm{M}$ in early summer of 2013. The highest concentrations of $\mathrm{NH}_{4}{ }^{+}$occurred following the drought, during the dry season when El Niño became established, when monthly average values $>40 \mu \mathrm{M}$ were noted (Fig. 4a). During WY2016, central bay $\mathrm{NH}_{4}{ }^{+}$concentrations averaged $15.9 \mu \mathrm{M}$, with a maximum individual recorded value of $80.1 \mu \mathrm{M}$ (Table 1). Concentrations of $\mathrm{NH}_{4}{ }^{+}$were also elevated from late 2017-mid 2018, with average monthly highs of 13.7-22.0 $\mu \mathrm{M}$ (Fig. 4a).

Concentrations of $\mathrm{NO}_{3}{ }^{-}$throughout the time course averaged $<0.50 \mu \mathrm{M}$, and monthly averages rarely exceeded $1.00 \mu \mathrm{M}$ during the entire time course (Fig. 4b). The highest concentrations were observed mid-drought, when average monthly concentrations for central bay were $>1 \mu \mathrm{M}$, with the highest individual value of $1.57 \mu \mathrm{M}$ (Table 1). Seasonal increases in $\mathrm{NO}_{3}{ }^{-},>1.00 \mu \mathrm{M}$, were also observed in mid 2018 and 2019.

Monthly concentrations of $\mathrm{PO}_{4}^{-3}$ averaged $<0.05 \mu \mathrm{M}$ throughout the time course (not shown). The maximum individual value, $0.16 \mu \mathrm{M}$, was observed during the drought period (Table 1).
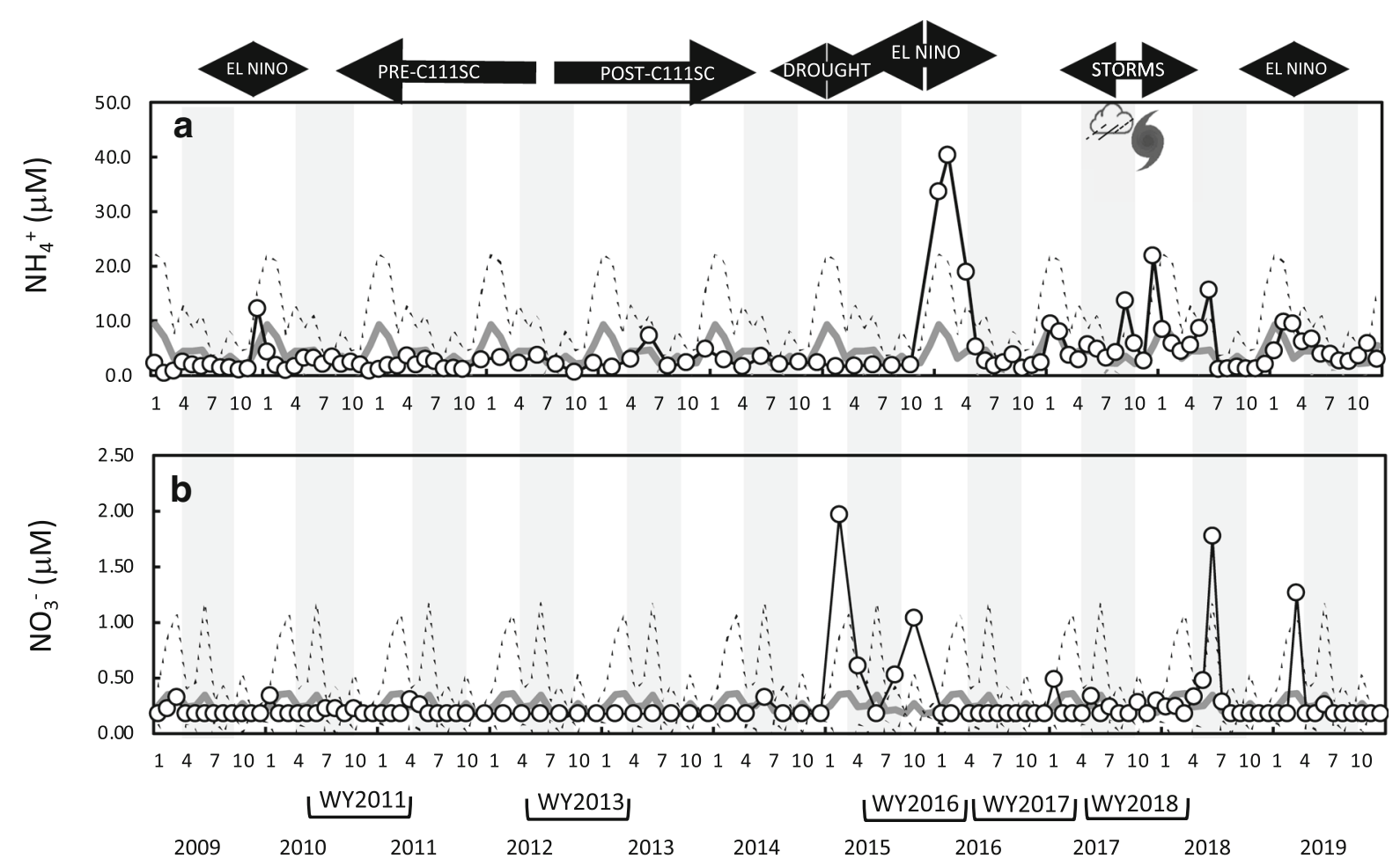

Fig. 4 As for Fig. 3, except for concentrations of $\mathbf{a ~} \mathrm{NH}_{4}{ }^{+}, \mathbf{b ~ N O}{ }_{3}$ 
Inorganic molar $\mathrm{N}: \mathrm{P}$ ratios increased significantly from an average of $58 \pm 44$, with a maximum observed value of 245, during WY2011 which was pre-C111SC, to an average of $418 \pm 577$ (with a maximum individual value of 2485) during the 2015 drought. From these highs, these ratios declined significantly during the late El Niño and storm periods of 2015-2017, but not to the low levels of pre-and post-C111SC (Table 1).

\section{Organic nutrients}

Organic nutrients had a different pattern than those of the inorganic nutrients when the entire time course is considered. Whereas $\mathrm{NO}_{3}{ }^{-}$increased significantly during the drought period (but nevertheless remained low, $<2 \mu \mathrm{M}$ ), and $\mathrm{NH}_{4}{ }^{+}$increased with progression of the strong El Niño in 2015, the organic nutrients showed the largest increase in response to the storm periods of 2017 (Fig. 5). No significant differences were observed in dissolved organic nutrient (DON) pre- and post-C111SC and the drought, with values rising during the wet periods and declining during the dry periods and all values for the central bay during these times falling within 1 standard deviation of the long-term average (Fig. 5a, Table 1). However, late in 2016, toward the end of El Niño, DON values rose (Fig. 5a). Values of DON during WY2017 and WY2018 were significantly higher compared to water years earlier in the time series (Table 1).

For dissolved organic $\mathrm{P}$ (DOP), all values up to the middle of the drought were less than the long-term mean (Fig. 5b). As with DON, values increased significantly during the late El Niño period of 2015 and increased even more substantially during wet season of the storm periods and the year following (Fig. 5b, Table 1). Average values for the WY2017 during the late El Niño period were about twofold higher than during the pre- and post-C111SC periods, and increased another 50\% for the WY2018, which encompassed the storms. Maximal individual values for WY2018 were about fivefold higher than maximal values observed early in the time series (Table 1).

For dissolved organic carbon (DOC), no significant differences were seen between the individual water years examined (Table 1), although the variability in average central bay values increased in the latter years of the time series (Fig. 5c). The highest individually recorded value occurred in WY2018 (Table 1).
Chlorophyll $a$ and turbidity

For the time series as a whole, average monthly Chl $a$ values ranged from lows of $<1 \mu \mathrm{g} \mathrm{L}^{-1}$ during the dry season, to highs of $\sim 5 \mu \mathrm{g} \mathrm{L}^{-1}$ in the late wet season (Fig. 6a). In late 2009, toward the end of that El Niño period, and also in late 2012 following C111SC implementation, monthly $\mathrm{Chl} a$ concentrations increased to just above $5 \mu \mathrm{g} \mathrm{L}^{-1}$. Monthly averages, up to $13.3 \mu \mathrm{g} \mathrm{L}^{-1}$, were seen toward the end of the 2015-2016 El Niño period and up to $23.7 \mu \mathrm{g} \mathrm{\textrm {L } ^ { - 1 }}$ following the storm events of 2017. The highest individual Chl $a$ value recorded was $53.10 \mu \mathrm{g} \mathrm{L}^{-1}$ during WY2018 (Table 1). The years following the storm events of 2017 also witnessed high Chl $a$ values in the late wet season as the last El Niño of the time series became established (Fig. 6a).

Water turbidity (NTU values) generally followed the patterns in Chl $a$, that is, being comparatively low (i.e., high transparency) through the early phases of the time series and increasing significantly during the storm period of 2017 (Fig. 6b, Table 1). Turbidity values in WY2018 were more than fourfold higher than those of W2011, with highest recorded value of that time being more than tenfold higher than the highest observed value during the drought (Table 1).

\section{Commonalities across all periods}

Although concentrations varied across different periods, there were several common relationships with respect to both organic nutrients and the most common inorganic $\mathrm{N}$ form, $\mathrm{NH}_{4}{ }^{+}$when all data were considered. Concentrations of DON were significantly positively related to concentrations of DOC with a slope of $6.34(\mathrm{p}<0.01)$, but concentrations of DOP were not significantly correlated with DOC when all individual data are considered (Fig. 7a,b). The concentrations of both $\mathrm{NH}_{4}{ }^{+}$and DOP were significantly related to $\mathrm{pH}$, implying their direct association with organic input as flow increased (Fig. 7c,d).

Concentrations of Chl $a$ did not show any clear patterns with either salinity or temperature, although at salinities $>40$ and at temperatures $>30{ }^{\circ} \mathrm{C}$ large blooms did not accumulate, suggesting a limit to tolerance to those extreme conditions (Fig. 8a,b). Concentrations of Chl $a$ were directly and significantly related to concentrations of DOP and DON $\left(\mathrm{R}^{2}=0.75\right.$ and 0.44 , respectively, $\mathrm{p}<0.01$ in each case; 

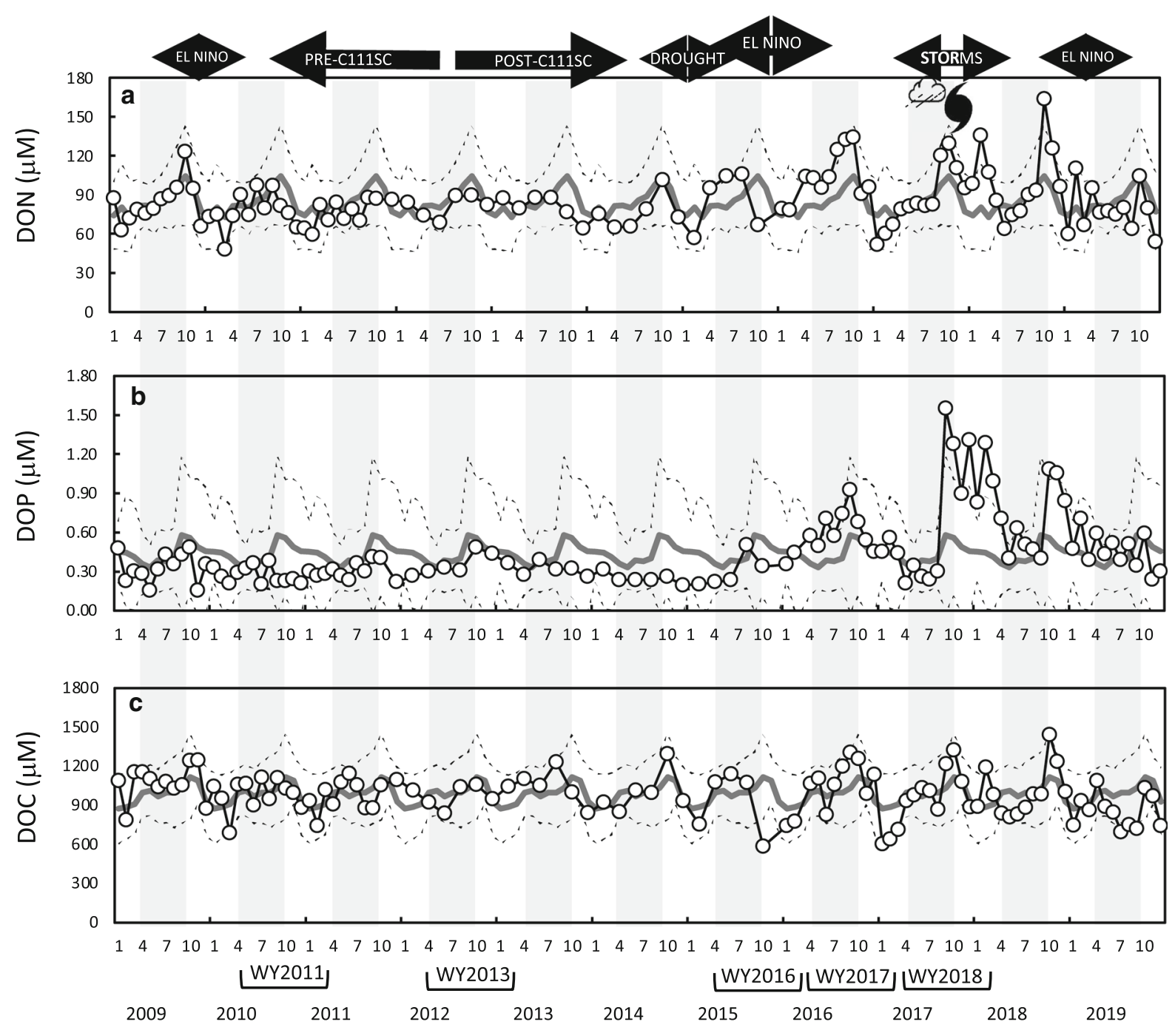

Fig. 5 As for Fig. 3, except for concentrations of a DON, b DOP, and c DOC

Fig. 8c,d). No direct relationships were found for $\mathrm{Chl}$ $a$ and concentrations of $\mathrm{PO}_{4}^{-3}$ or $\mathrm{NO}_{3}^{-}$(not shown), but concentrations of $\mathrm{Chl} a$ declined as concentrations of $\mathrm{NH}_{4}{ }^{+}$increased (Fig. 8e). However, it is of note that $\mathrm{Chl} a$ values in excess of $20 \mu \mathrm{g} \mathrm{L}^{-1}$ were observed when concentrations of $\mathrm{NH}_{4}^{+}$were $>40 \mu \mathrm{M}$. Concentrations of $\mathrm{Chl} a$ decreased as DON:DOP increased, reflecting $\mathrm{P}$ stress under the higher ratio conditions (Fig. 8f).

\section{Discussion}

Management of complex systems which are subject to long term change on a variety of scales is challenging. These climatological pressures occur under varying spatial and temporal scales, from local hurricanes, which are increasing in severity with climate change, to regional droughts, to larger scale global weather cycles such as El Niño-Southern Oscillation. These climatological pressures often overlap with ongoing local anthropogenic changes such as coastal development and eutrophication, further increasing the complexities of management. 

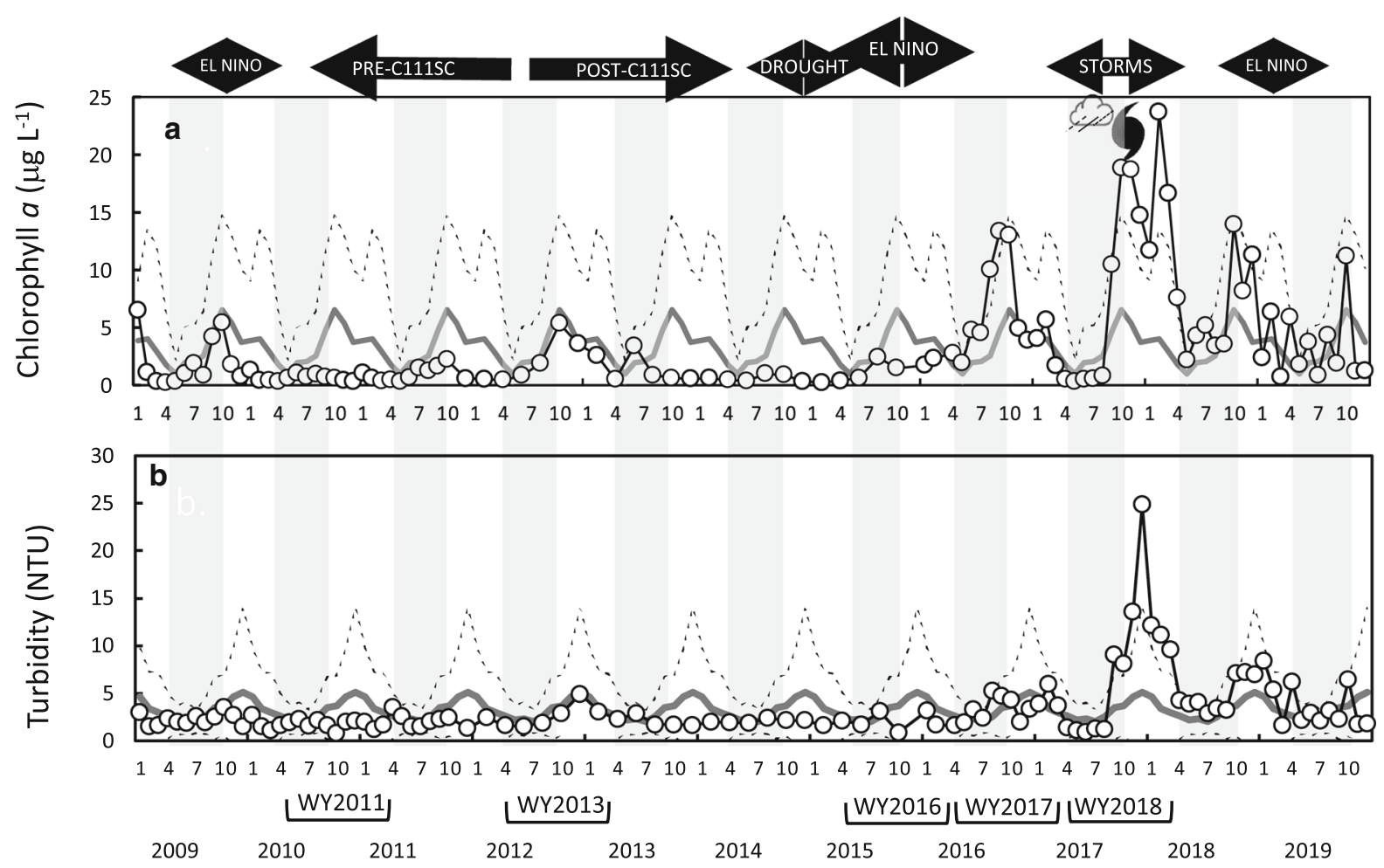

Fig. 6 As for Fig. 3, except for a chlorophyll $a$, and b turbidity)

Northern, central and eastern Florida Bay have classically been viewed as having nutrient availability that is typically in higher-than-Redfield ratio proportions, very low in inorganic $\mathrm{P}$, but high in DON, DOP and DOC (Powell et al. 1989; Fourqurean et al. 1992; Glibert et al. 2004; Boyer et al. 2006). Benthic productivity, which can access sedimentary $\mathrm{P}$, is typically higher than water column productivity in central and eastern bay (Fourqurean et al. 2002; Nielsen et al. 2006), and seagrasses have historically been more productive in the central bay region than in the eastern bay region (Fourqurean and Robblee 1999). Episodic periods of seagrass loss and picocyanobacterial blooms have occurred in Florida Bay over the past several decades. A decline in seagrass in fall 1987 destroyed 4000 ha of Thalassia spp., and thinned an additional 23,000 ha (Robblee et al. 1991), resulting in the loss of $30 \%$ of the community (Hall et al. 1999; Durako et al 2002). Maximum loss of Thalassia occurred in the highest density beds, especially in the north-central bay, and loss of this keystone species caused a cascade of ecological effects. Beginning in 1991, phytoplankton blooms dominated by the picocyanobacterium Synechococcus spp. began to appear in the central and western bay regions (Boyer et al. 1999; Stumpf et al. 1999) and have occurred sporadically since (Richardson and Zimba 2002; Glibert et al. 2004, 2009, 2010). Management of water quality has focused on re-establishing sufficient flow (and fresh water) to support seagrasses, but the interplay of freshwater flow and nutrient input-and the contrasting effects on seagrasses and phytoplankton blooms-needs to be more holistically considered.

There have been many studies addressing single drivers and their impacts on different aspects or biological components of the south Florida aquatic ecosystems, such as the impacts of hurricanes on phytoplankton (Briceño and Boyer 2010; Wachnicka et al. 2019; Peierls et al. 2003), mangroves (Lagomasino et al 2020), corals (Kobelt et al. 2019) and El Niño impacts on river flow and biotic responses (Schmidt et al. 2001; Abtew and Trimble 2010; Phlips et al. 2014), coastal salinity (Schmidt and Luther, 2002; Kelble et al. 2007) and seagrasses (Fourqurean and Rutten 2004; Carlson et al. 2010). However, the 

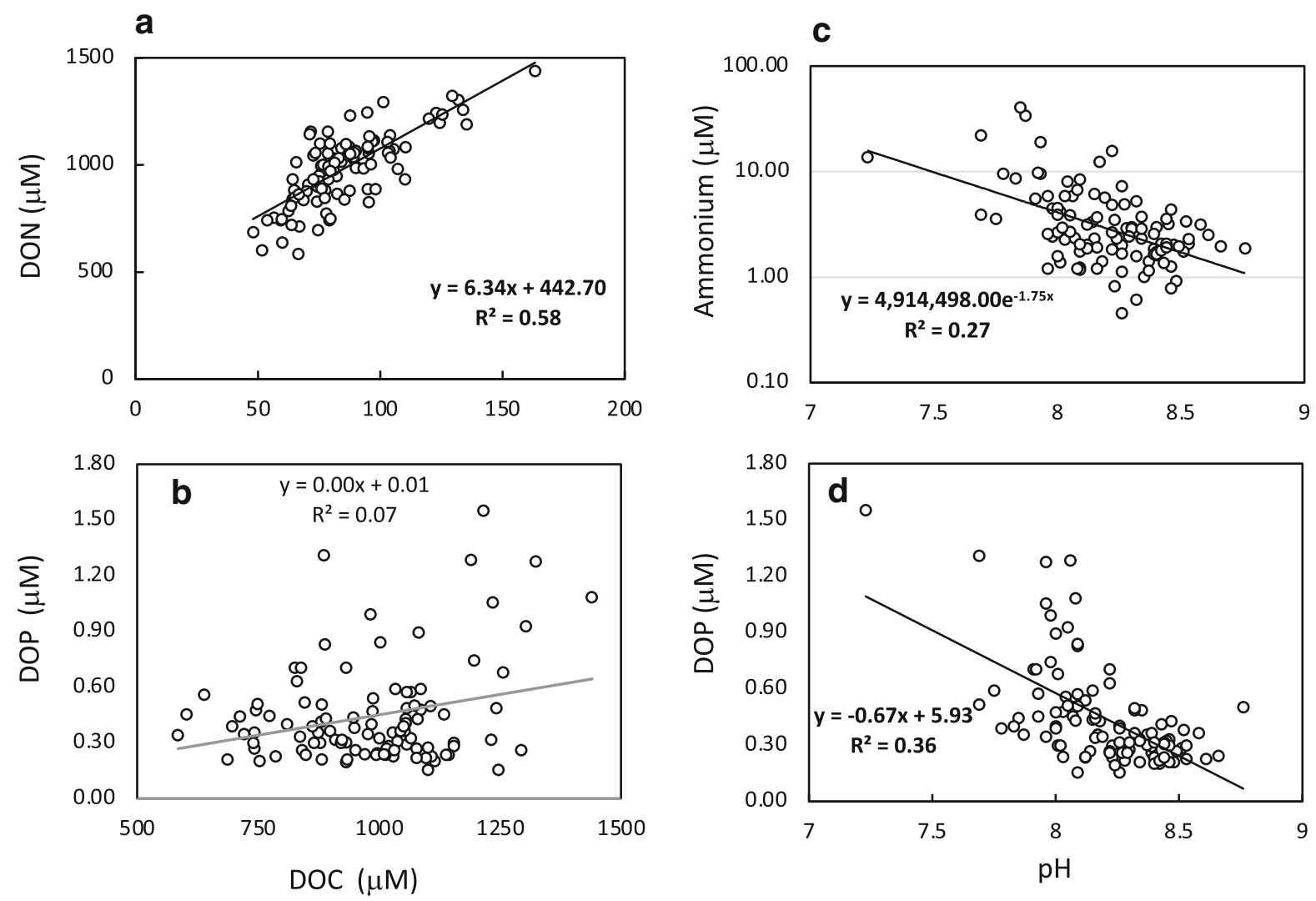

Fig. 7 Relationships between a DON and DOC, b DOP and DOC, $\mathbf{c ~} \mathrm{NH}_{4}{ }^{+}$and $\mathrm{pH}$ (note the log scale), and $\mathbf{d}$ DOP and $\mathrm{pH}$. Shown are the individual data points for all stations sampled in

majority of these studies address immediate postdriver impacts, and not the processes which underlie/drive this complex system and the component biotic responses. The Florida Bay data set analyzed here, monitored monthly or bimonthly for a variety of chemical, physical and biological parameters (Boyer and Briceño 2008; Glibert et al. 2009), has provided us a tool to assess the processes and cycling which underlie the impacts of long-term drivers in this system such as drought, hurricanes and El-Niño. The data period examined here includes discrete temporal and spatial periods where these large-scale pressures dominated the meteorology and hydrology of the region. Each period resulted in unique responses in terms of downstream hydrological conditions, nutrient loads, seagrass stress and picocyanobacterial blooms. Here, different stressors are discussed in terms of biogeochemical effects and physiological responses and a conceptual model is presented for how and why

central bay for all monthly or bimonthly samples collected from 2009 to 2019. All relationships indicated in bold font were significant at $\mathrm{p}<0.01$

picocyanobacteria blooms occurred when they didand why they were displaced in time from the droughtrelated seagrass die-off (Fig. 9).

Seagrass die-offs: relationships to drought and other stressors

Salinity has long been hypothesized to be a major stressor for the dominant seagrass, Thalassia sp., in the central bay, and hyper-salinity has been associated with previous die-offs (Zieman et al. 1989, 1999; Robblee et al. 1991; Fourqurean et al. 1993; McIvor et al. 1994). Hyper-salinity occurs in Florida Bay when flow is reduced, and the drought of 2015-2016 exemplifies this. Exceptionally high salinity was associated with the die-off in 2015 (Fig. 1e), as the drought not only led to central bay individual salinity values in excess of 75 in what would normally be considered the wet season, but the prior dry season 

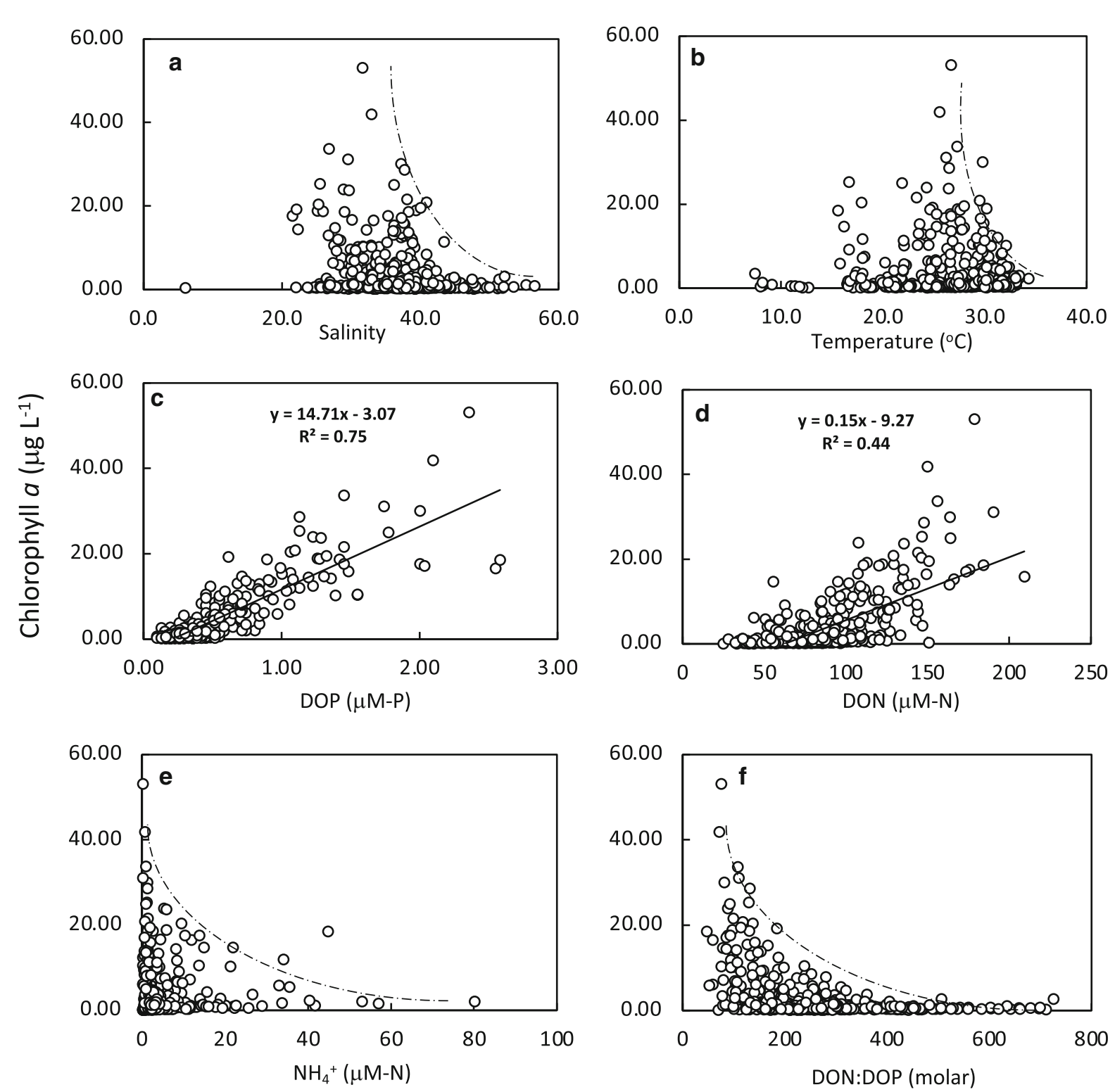

Fig. 8 Relationships between chlorophyll $a$ and various water quality parameters, including a salinity, $\mathbf{b}$ temperature, $\mathbf{c}$ DOP, d DON, e $\mathrm{NH}_{4}{ }^{+}$, and $\mathbf{f}$ DON:DOP molar ratio. Panels depict all individual values for the 4 central bay stations analyzed here for the time series from 2009 to 2019 . Regression analysis is shown for panels (c) and (d); both were significant at $\mathrm{p}<0.01$. The

(late 2014-early 2015) also witnessed salinity values much higher than the normal range (Fig. 3a, 9a).

As halophytes, seagrasses can normally withstand a wide range of salinities (Touchette 2007). Many physiological characteristics of seagrass change with salinity, including photosynthetic capacity, growth, pigment content, biomass and $\mathrm{C}: \mathrm{N}$ composition dashed lines in panels (a), and (b) depict the rapid decline in chlorophyll $a$ as salinity and temperatures values increase above 40 and $30{ }^{\circ} \mathrm{C}$, respectively. The dashed line in panels (e) and (f) depict the general upper bound of chlorophyll $a$ concentrations with increasing concentrations of $\mathrm{NH}_{4}{ }^{+}$and increasing ratios of DON:DOP

(Fernández-Torquemada and Sánchez-Lizaso 2011; Sandoval-Gil et al. 2012; Garrote-Moreno et al. 2015, Piro et al. 2015). Several studies have been conducted to study salt tolerance in both temperate and tropical seagrasses (Koch et al. 2007; reviewed by Touchette 2007, Sandoval-Gil et al. 2014, Collier et al. 2014) and most seagrasses are thought to be sensitive to 

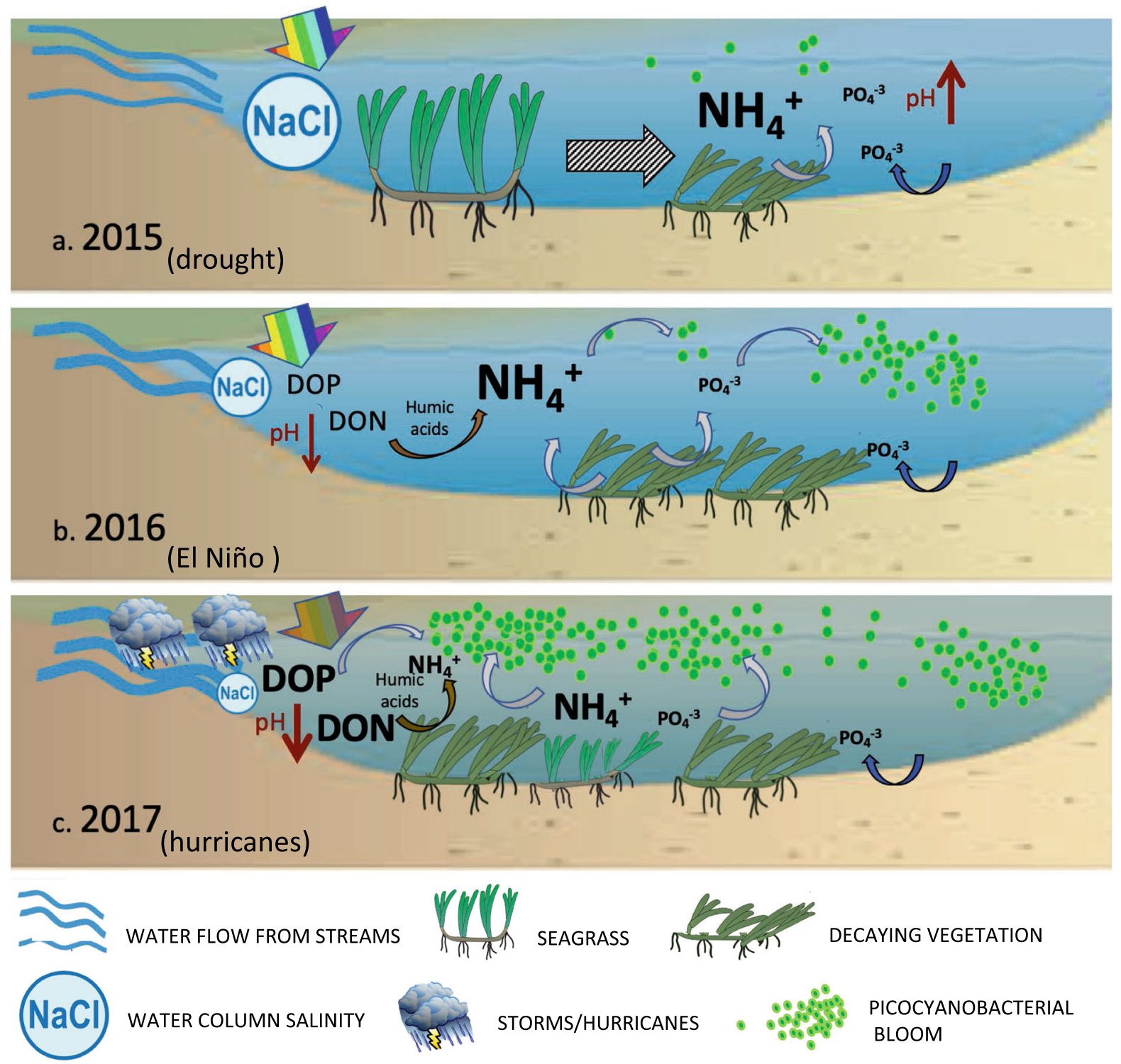

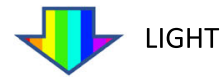

Fig. 9 Conceptual relationships between various environmental factors and biotic responses for the a drought period (2015), b the El Niño period (2016), and $\mathbf{c}$ the storm/hurricane period (2017). Key symbols for the diagram (obtained from the University of Maryland Integration and Application Network) are indicated along the bottom of the panel. The size of the

hyper-salinity (Ogata and Matsui 1965; Biebl and McRoy 1971; Zieman 1975; Adams and Bate 1994; Kamermans et al. 1999; Van Katwijk et al. 1999). Koch et al. (2007) tested the response of three local tropical seagrass species to hyper-salinity, induced

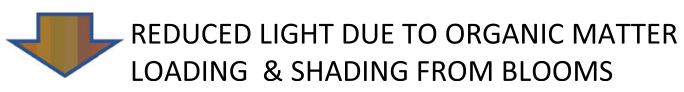

symbol or font indicates relative magnitude of the parameter or process. Processes highlighted include the die-off of seagrass due to hyper-salinity in 2015, increased $\mathrm{NH}_{4}{ }^{+}$in 2016 and beginning of an algal bloom, and the large algal bloom in 2017 sustained by high organic nutrient loads and associated inorganic nutrients

slowly and also pulsed. Sensitivity to hyper-salinity was found to be a function of adjustment time, i.e., a slow osmotic adjustment period vs rapid pulsed exposure, duration of exposure, and the presence or absence of other co-occurring stressors such as light 
and temperature (Koch et al. 2007). Based on growth and photosynthetic parameters, they demonstrated that while Thalassia testudinum and Halodule wrightii are able to tolerate salinities of 60 and 65 , respectively, high salinity alters photosynthesis, increases respiration, in turn altering the $\mathrm{C}$ and $\mathrm{O}_{2}$ balance in the plant, potentially affecting the long-term health of the seagrass community (Johnson et al. 2018).

While seagrasses in Florida Bay are able to tolerate short periods of hyper-salinity, extended exposure renders them increasingly vulnerable to both further hyper-salinity exposure as well as other stressors they normally would be able to tolerate. Exceptionally high $\mathrm{NH}_{4}{ }^{+}$values, herein termed hyper- $\mathrm{NH}_{4}{ }^{+}$conditionsup to $80 \mu \mathrm{M}$, developed in the season following the die-off event at the latter stages of the 2015 El Niño (Fig. 4 a, 9b, Table 1). Resulting from benthic remineralization, as well as release by benthic organisms such as sponges (e.g., Hoer et al. 2020), the concentrations of $\mathrm{NH}_{4}{ }^{+}$accumulated to levels that were likely stressful and inhibiting to recovery. Effects of elevated $\mathrm{NH}_{4}{ }^{+}$on macrophytes have previously been documented, but mostly in freshwater species (e.g., Cao et al. 2007, 2011; Nimptsch and Pflugmacher 2007; Apudo et al. 2016; Zhou et al. 2017). As with phytoplankton, the concentrations of $\mathrm{NH}_{4}{ }^{+}$ yielding stress responses varies with species and environmental conditions. Effects of high $\mathrm{NH}_{4}{ }^{+}$ include reductions in photosynthetic yield (as Fv/ Fm), changes in cellular composition, and increased vulnerability to hydraulic damage and breakage due to changes in structural stiffness and other properties (Apudo et al. 2016).

Picocyanobacterial blooms: interactions with organic nutrients and role of $\mathrm{pH}$

Picocyanobacterial blooms did not develop until late 2016, but the largest and more sustained blooms occurred in late 2017 through 2018 (Fig. 6a). They did not develop in the hyper-salinity conditions of 2015 (Fig. 8a), and low Chl $a$ was the norm during hot summer months (Fig. 6a, 8b). The biogeochemical and physiological mechanisms leading to the picocyanobacterial blooms that occurred from 2017 to 2018 appear to be complex, involving interactions of organic loads, inorganic and organic nutrients, and
$\mathrm{pH}$-all of which appear to have changed as freshwater inflow changed during the storm period.

Recent work has shown that the phenomenon of brownification, the enrichment of aquatic systems with organic acids (e.g., Granéli 2012), may synergistically interact with warming waters favoring the development of cyanobacterial blooms in fresh waters (Urrutia-Cordero et al. 2016, Williamson et al. 2015). Herein a conceptual framework is suggested that also invokes similar synergistic interactions that favored picocyanobacteria growth as rainfall and freshwater flow increased (Fig. 9).

The trend in $\mathrm{pH}$ over the decade studied here is consistent with the global declining trends in $\mathrm{pH}$ in the ocean, i.e., ocean acidification (e.g., Bates et al. 2015). However, there is much evidence that $\mathrm{pH}$ changes in shallow, near-shore waters are more complex than those resulting from ocean acidification (Hofmann et al. 2011; Enochs et al. 2019)-especially when those waters have long residence times or restricted flow. Here, the highest $\mathrm{pH}$ values were observed during the drought and lowest values were noted during the period of intense storms and late El Niño (Figs. 3, 9, Table 1). The origin of the low $\mathrm{pH}$ water cannot be determined with absolute certainty with the current data, but fresh waters, which are generally oversaturated with $\mathrm{CO}_{2}$ (e.g., Cole et al. 1994), are less well buffered than marine waters and may have lower $\mathrm{pH}$ values. The bloom that occurred in late 2017, reaching an average of $\sim 20 \mu \mathrm{g} \mathrm{L}^{-1}$ in central bay (Fig. 6a), directly coincided with the sharp large drop in $\mathrm{pH}$ to a value of 7.2 that occurring during the storm period (Fig. 3b).

While actively growing algae can result in elevated $\mathrm{pH}$ due to their draw-down of $\mathrm{CO}_{2}$ (e.g., Gao et al. 2012; Yang et al. 2017), the microbial breakdown of organic matter can lead to elevated $\mathrm{CO}_{2}$, and thus decreased $\mathrm{pH}$, via increased respiration (Cai et al. 2011; Wallace et al. 2014). Accordingly, the drop in $\mathrm{pH}$ over time is also consistent with increased heterotrophy from decaying seagrass and other organic matter from water that traversed the Everglades. As shown by Enochs et al. (2019), inlets in southeast Florida can act as acidification hotspots, driven by high organic $\mathrm{C}$ respiration. Enochs et al. (2019) attributed drops in $\mathrm{pH}$ in these inlets to eutrophication and delivery of organic-rich freshwater inputs, and the same inference is drawn herein. Organic acids can be delivered with freshwater flow, 
especially following drought-accumulation of inorganic and organic nutrients on land, strongly influencing the carbonate chemistry of receiving aquatic systems (Aufdenkampe et al. 2001, 2011; Duarte et al. 2013). Spatial surveys of Florida Bay-for earlier years than reported in this study-showed that low $\mathrm{pH}$ waters with high levels of inorganic $\mathrm{C}$ correlated with lower salinity (Millero et al. 2001). Moreover, that study suggested that oxidation of organic matter near the mangrove fringe would result in higher $\mathrm{CO}_{2}$ and lower $\mathrm{pH}$, in turn, leading to higher $\mathrm{PO}_{4}{ }^{3-}$ from dissolution of carbonate sediments (Millero et al. 2001).

Concentrations of humic acids, the naturally occurring, colored, high molecular weight organic acids produced by the degradation of plant material, increase directly as flow increases. The flow path of fresh water through the Everglades is rich in organic material, and freshwater inputs tend to be high in DON and DOC (Fig. 5, Glibert et al. 2009, Shangguan et al. 2017a, b and references therein, Wilson et al. 2018). Humic material in eastern Florida Bay has been previously documented to be primarily terrestriallyderived and can vary by as much as 11-fold, with increases following input from the mainland, whether from controlled releases or natural flow (Brown 1987). Whether these humics originate from surface runoff or from ground water, there is active ion exchange during the rainy season and mixing with microbially-derived humic-DOM along the estuarine gradient (Chen et al. 2010; Timko et al. 2014). Qualls and Richardson (2003) quantified the DOC at the Everglades-Florida Bay transition as being composed of $50 \%$ humic substances, $33 \%$ hydrophyilic acids and 15\% hydrophobic neutral substances, and confirmed that the major sources were terrestrial but that plant production and microbial decomposition and solar radiation modify this material.

During intensive storms, the delivery of such organic material may be even greater. Strong storms can result in increased turbulence that increases scour near roots and trunks of nearshore vegetation, accelerating dieback. When this happens, organic matter and nutrient delivery not only is increased but a cascade of responses begins that further accelerates erosion, leading to increasing nutrient delivery from land-based sources (Wanless et al. 2012; Engel 2012). For example, many of Florida's mangroves and SAV beds were torn up in Hurricanes Katrina and Rita in 2005 and have not yet recovered (Witman 2018).
Hurricane Irma was found to have damaged some mangroves and to uproot recovering seagrasses (e.g., Wilson et al. 2020). Regardless of whether these organic materials were carried with fresh water or generated from damaged benthic macrophyte communities, there is no doubt that water column concentrations of organic nutrients increased: values of DON and DOP were significantly higher in the latter water years, in the late $2015 \mathrm{El}$ Niño and the 2017 storm periods (Table 1), with DON and DOC tracking in parallel (Fig. 7a).

Even though this data set does not permit analysis of the chemical composition of the organic material, there is no question that concentrations increased during the storm period. If, indeed, humic concentrations increased, there is also potential for it to have elicited direct stress responses, as has been shown for many phototrophs, including production of hydroxyl radicals (Lee et al. 2013; Zhang et al. 2014). But Synechococcus is known to have exceptional tolerance to high light, salt and other environmental stresses and recent evidence suggests that at least one strain of Synechococcus is relatively tolerant of the negative effects of humic substances on photosynthesis unless the temperatures are much greater than $27^{\circ} \mathrm{C}$ (Korosh et al. 2018). The potential for additional interactions between organic compounds and inorganic nutrient availability are discussed below.

Picocyanobacterial blooms: inorganic and organic phosphorus

Concentrations of both $\mathrm{PO}_{4}{ }^{3-}$ and DOP in the eastern bay are typically low to undetectable due to $\mathrm{P}$ scavenging and sequestering by calcium carbonate sediments and Everglades marl (Glibert et al. 2004, Nielson et al. 2006). Concentrations of $\mathrm{PO}_{4}{ }^{3-}$ values remained at or near the analytical limit of detection throughout the time course studied herein (Table 1). Whereas the eastern bay region is generally considered to be severely P-limited (Fourqurean et al. 1992; Hitchcock et al. 1998; Lavrentyev et al. 1998), the central bay generally has been thought to have sufficient total dissolved $\mathrm{N}$ and $\mathrm{P}$ (inorganic and organic) to support normal phytoplankton growth (Boyer et al. 1999; Fourqurean and Robblee 1999). Most of the $\mathrm{P}$ in the central to eastern bays is present in the sediments either in the solid phase as loosely bound oxy-hydroxides or as apatite (Koch et al. 2001). 
The low $\mathrm{PO}_{4}{ }^{3-}$ concentrations may also be exacerbated by the presence of humic acids. Humic acids have carboxyl groups that can compete for $\mathrm{P}$ adsorption sites (Fu et al. 2013; Perassi and Borgnino 2014; Urrutia et al. 2014; Wang et al. 2016). The extremely high DIN:DIP values, and very low $\mathrm{PO}_{4}{ }^{3-}$ values, observed during the storm periods (Table 1) would be consistent with this mechanism. These humic acid complexes have variable stability with $\mathrm{P}$, a function of metallic cations, and solubilization can occur especially at the relatively higher $\mathrm{pH}$ noted earlier in the time series, but this would not be the case at the lower $\mathrm{pH}$ values noted later in the time series. On the other hand, during the latter phases of the time course, the availability of DOP increased significantly coincident with the decline in $\mathrm{pH}$ (Fig. 7d, Table 1).

Chronic, exceptionally low $\mathrm{PO}_{4}{ }^{3-}$ conditions favor phytoplankton taxa that either have a low $\mathrm{PO}_{4}{ }^{3-}$ demand or can substitute an alternative P source (e.g., Glibert and Burkholder 2011). Synechococcus spp. has a low $\mathrm{PO}_{4}{ }^{3-}$ affinity (i.e., a high half saturation value for inorganic $\mathrm{P}$ uptake kinetics), and at least one strain of Synechococcus appears to carry homologs of the E. coli low-affinity $\mathrm{PO}_{4}{ }^{3-}$ transporter (Dyhrman and Haley 2006; Scanlan et al. 2009; Bench et al. 2013). Synechococcus spp. may overcome this low $\mathrm{PO}_{4}{ }^{3-}$ affinity through several mechanisms. First, when water column $\mathrm{pH}$ conditions are elevated, enhancement of sediment $\mathrm{P}$ release may occur. The looselybound $\mathrm{P}$ in oxy-hydroxides would be released as $\mathrm{pH}$ increases (e.g., Koch et al. 2001). Sediment release of $\mathrm{P}$ with increases in $\mathrm{pH}$ has been observed in eutrophic lakes (i.e., Andersen 1974; Drake and Heaney 1987; Jensen and Andersen 1992; Xie et al. 2003) and tidal freshwater/oligohaline estuaries (Seitzinger 1991; Glibert et al. 2011; Gao et al. 2012).

Synechococcus also has an ability to substitute P-containing lipids with non-P containing lipids in membranes (Van Mooy et al. 2009), a P-sparing mechanism. It has a high affinity for DOP, as documented by its alkaline phosphatase activity (APA; Glibert et al. 2004; Heil et al. 2009; Koch et al. 2009). With few individual exceptions, DOP increased over time in the late El Niño and storm periods (Fig. 5b, Table 1), giving those phytoplankton able to use this form greater access to this nutrient. The strong direct correlation between DOP availability and Chl $a$ availability (Fig. 8c) underscores the importance of this form of $\mathrm{P}$ to the cyanobacteria. High APA has been documented in Synechococcus spp.-dominated blooms in central Florida Bay in October 2002 (Glibert et al. 2004), and in the eastern Florida Bay from June 2005 through 2008 (Glibert et al. 2009), and in other Synechococcus-dominated communities (e.g., Grillo and Gibson 1979; Ray et al. 1991; Li et al. 1998). It has been shown that Synechococcus possesses both $\mathrm{PO}_{4}{ }^{3-}$ repressible and $\mathrm{PO}_{4}{ }^{3-}$ irrepressible alkaline phosphatases (Wagner et al. 1995), and at least one strain has atypical alkaline phosphatase (Grossman 1991). Previously-documented continual presence of measurable amounts of dissolved APA throughout eastern and central Florida Bay suggest that Synechococcus spp. blooms may also benefit from a continual supply of $\mathrm{PO}_{4}{ }^{3-}$ from water column DOP hydrolysis and UV hydrolysis of P-Fe humic complexes (Heil et al. 2009).

Picocyanobacterial blooms: ammonium and nitrate

Under most conditions of normal to extreme flow, there is typically residual $\mathrm{NH}_{4}{ }^{+}$in the water column in Florida Bay (Fig. 4a, Glibert et al. 2004). Based on energetic considerations, $\mathrm{NH}_{4}{ }^{+}$has long been considered to be the preferred $\mathrm{N}$ substrate for phytoplankton uptake, and the same is true for most plants, including seagrass (e.g., Raven et al. 1992). However, under some conditions, $\mathrm{NH}_{4}{ }^{+}$may actually be repressive or inhibitory to the growth of macrophytes and some phytoplankton (e.g., Dortch 1990; Cochlan and Harrison 1991; L'Helguen et al. 2008; Dugdale et al. 2007, 2012; Glibert et al. 2016). This more contemporary view has led to $\mathrm{NH}_{4}{ }^{+}$being characterized as a "paradoxical" $\mathrm{N}$ nutrient; preferentially used at the low end of the availability spectrum while considered inhibitory or toxic at the elevated end of the concentration spectrum (e.g., Dugdale et al. 2007, 2012; Glibert et al. 2016), a phenomenon also well documented in higher plants (Britto and Kronzucker 2002, 2013). Picocyanobacteria such as Synechococcus spp. are not inhibited by such elevated $\mathrm{NH}_{4}{ }^{+}$ concentrations; they may be better adapted to the use of $\mathrm{NH}_{4}{ }^{+}$and may tolerate proportionately higher concentrations of $\mathrm{NH}_{4}{ }^{+}$than many other taxa (Collos and Harrison 2014; Glibert et al. 2010, 2016). The ability of picocyanobacteria to tolerate $\mathrm{NH}_{4}{ }^{+}$concentrations that are harmful to other taxa is attributed, at least in part, to their small size; they cannot 
accumulate high internal $\mathrm{NH}_{4}{ }^{+}$concentrations (Glibert et al. 2010, 2016). Concentrations of $\mathrm{Chl}$ $a>20 \mu \mathrm{g} \mathrm{L}^{-1}$ in the picocyanobacterial blooms developed at $\mathrm{NH}_{4}{ }^{+}$concentrations as high as $40 \mu \mathrm{M}$ (Fig. 8e).

There are multiple sources that contribute to the accumulation of high residual $\mathrm{NH}_{4}{ }^{+}$concentrations. In addition to the remineralization of organic matter or benthic animal regeneration noted above, the interconnected, quasi-enclosed saline lakes located at the southern end of the Everglades that discharge into northern Florida Bay may be a source of $\mathrm{NH}_{4}{ }^{+}$ (Shangguan et al. 2017a). Previously documented changes in nutrient export from the ICOLLs following C111SC implementation suggested a shift to increasing export of chemically-reduced forms of $\mathrm{N}$, including $\mathrm{NH}_{4}{ }^{+}$and DON compared to $\mathrm{NO}_{3}{ }^{-}$as flow increased with the first phases of CERP (Shangguan et al. 2017a).

Another likely source of $\mathrm{NH}_{4}^{+}$is chemical exchange from the organic-rich material, including humic acids, that were likely delivered with the increased freshwater flow that occurred after the drought. Herein $\mathrm{NH}_{4}{ }^{+}$, DON, DOP and DOC all increased in the latter time periods considered (Table 1; Figs. 5,7). The largest fraction of $\mathrm{N}$ in humic material is $\mathrm{NH}_{4}^{+}$, loosely bound and extractable via solid phase extraction (e.g., Cochlan and Bronk 2003). Humic substances can incorporate $\mathrm{NH}_{4}{ }^{+}$into their structure either directly through chemical reactions or indirectly through microbial activities and subsequent decomposition of microbial biomass (e.g., Clinton et al., 1995). This $\mathrm{N}$ may be released from humic material via photooxidation and by ion exchange reactions, especially as salinities increase, as would be the case as fresh water intercepts more estuarine waters (e.g., Bushaw et al. 1996; See et al. 2006). The transport of increasing concentrations of DOM resulting from increasing flow may thus be potentially increasing $\mathrm{N}$ inputs into these bay waters by acting as a shuttle: $\mathrm{NH}_{4}{ }^{+}$in upstream waters associated with DOM is released during transport along the increasing salinity gradient. Additionally, both $\mathrm{NH}_{4}{ }^{+}$and urea have been shown to be breakdown products of humic material when exposed to UV (e.g., Bushaw-Newton and Moran 1999), also likely in the relatively clear, shallow waters of Florida Bay. Thus, warm temperatures, high light levels and resulting high salinities alter the chemical environment that primary producers are exposed to in ways that are more chemically complex than simple salinity increases, and involve ion exchange reactions with $\mathrm{N}$ and highly variable $\mathrm{pH}$.

While $\mathrm{NH}_{4}{ }^{+}$concentrations were consistently high-and higher still-following the 2015 El Niño and 2017 storm events, concentrations of $\mathrm{NO}_{3}{ }^{-}$ remained consistently very low (Fig. 5). The sustained low concentrations of $\mathrm{NO}_{3}{ }^{-}$throughout the entire time series might be interpreted as rapid uptake by the biota, but picocyanobacteria disfavor $\mathrm{NO}_{3}{ }^{-}$as an $\mathrm{N}$ substrate. The cellular $\mathrm{NO}_{3}{ }^{-}$transporters in these cyanobacteria are structurally and evolutionarily different from the $\mathrm{NO}_{3}{ }^{-}$transporters of diatoms, leading to lower affinity for $\mathrm{NO}_{3}{ }^{-}$than in diatoms (Glibert et al. 2016). Previous ${ }^{15} \mathrm{~N}$ measurements of direct uptake of $\mathrm{NO}_{3}{ }^{-}$in Florida Bay phytoplankton showed an inverse relationship between the percent contribution of $\mathrm{NO}_{3}{ }^{-}$to total uptake and the fraction of cyanobacteria in the community (Glibert et al. 2004), but a positive relationship with the fraction of diatoms. Diatoms are the dominant protists in cool, $\mathrm{NO}_{3}{ }^{-}$-rich water columns during spring blooms, (e.g., Kudela and Dugdale 2000; Wilkerson et al. 2000) and in Florida Bay are found predominantly in the northern bay where higher concentrations of $\mathrm{NO}_{3}{ }^{-}$can be observed (Shangguan et al. 2017a). Phlips et al. (2014) found that diatoms increased in the lagoons of eastern Florida following the cool, El Niño winter of 2009, but the subsequent summer and fall witnessed picocyanobacterial blooms; no measurements were made of $\mathrm{NH}_{4}{ }^{+}$in that study.

More likely explanations of the sustained low $\mathrm{NO}_{3}{ }^{-}$concentrations involve truncation of the $\mathrm{N}$ cycle, including low rates of nitrification and denitrification. Substrate availability (i.e., $\mathrm{NH}_{4}{ }^{+}$concentration) for nitrification is clearly not a limiting factor. High summer water temperatures $\left(\sim 35^{\circ} \mathrm{C}\right)$ may inhibit nitrifying bacteria (e.g., Zheng et al. 2017). Also, rates of nitrification during the early phases of the time course may be low due to elevated $\mathrm{pH}$ (e.g., Huesemann et al. 2002, Kemp et al. 2005), as pH is known to be an important regulator of $\mathrm{NH}_{3}$ oxidizer communities (e.g., Damashek and Francis 2018). Both bacterial production and respiration can be negatively affected by higher $\mathrm{pH}$ values, which reduce rates of remineralization (Tank et al. 2009). As pH declined, higher concentrations of $\mathrm{NO}_{3}{ }^{-}$were observed (up to $2 \mu \mathrm{M})$ during the drought and in the years following 
the storm events, in all cases being highest at the end of the dry season or early wet season. Similarly, Hampel et al. (2020) observed increases in nitrification in Lake Okeechobee and St Lucie Estuary, Florida, following Hurricane Irma. Thus, if nitrification is inhibited by temperature of $\mathrm{pH}$, any available $\mathrm{NH}_{4}{ }^{+}$would remain as $\mathrm{NH}_{4}{ }^{+}$or $\mathrm{NH}_{3}$ and would not be converted to $\mathrm{NO}_{2}{ }^{-}$ or $\mathrm{NO}_{3}{ }^{-}$at a substantial rate.

Denitrification rates have also been shown to be very low in Florida Bay. Gardner and McCarthy (2009), using isotopic tracer techniques, showed that almost no $\mathrm{N}_{2}$ was produced by added $\mathrm{NO}_{3}{ }^{-}$ especially in summer when cyanobacterial blooms were observed. Instead, these authors observed that rates of dissimilatory $\mathrm{NO}_{3}{ }^{-}$reduction to $\mathrm{NH}_{4}{ }^{+}$were high in the summer, providing yet another potential source of $\mathrm{NH}_{4}{ }^{+}$.

Picocyanobacterial blooms: other contributing factors

Grazing does not appear to control blooms when they occur, and bottom-up factors overwhelm top-down considerations except in late stages of blooms (e.g., Dagg and Ortner 1996; Phlips et al. 1999; Glibert et al. 2009). The hyper- $\mathrm{NH}_{4}{ }^{+}$concentrations that developed during the El-Niño of 2015 would also negatively impact microzooplankton (Glibert et al. 2016).

Light decreased (as turbidity increased nearly fourfold) in the post-Irma period relative to the preand post-CERP years as well as the early and late drought years (Table 1, Figs. 6b, 9c). Increased turbidity in prior years (early 1990s) in Florida Bay was associated with increased resuspension of carbonate bottom sediments (Boyer et al. 1999), a consequence of seagrass loss with their associated sediment binding ability (Hunt and Nuttle 2007). Increased turbidity observed following the storm period of 2017 and 2018 also corresponded with high Chl $a$ accumulations due to the picocyanobacterial blooms. This shading would not only reduce photosynthetically active radiation, but also UV radiation, potentially contributing to community compositional changes. While some cyanobacterial species may adapt to high light, including high UV (e.g., Kirk 2011), reduced light levels may also promote preferential growth of small-sized phytoplankton because of their large surface to volume ratio (Raven 1998), again favoring picocyanobacteria. This was recently also demonstrated by Marzetz et al. (2020), who showed that compared to other phytoplankton groups (including a diatom, cryptophyte and green alga), cyanobacteria (including $S$. elongatus) developed higher biomass at lower light intensities than the other taxa.

In all, cyanobacteria such as Synechococcus appear to have numerous physiological mechanisms to make them uniquely tolerant of episodically high $\mathrm{NH}_{4}{ }^{+}$, as well as chronically low $\mathrm{NO}_{3}{ }^{-}$and low $\mathrm{PO}_{4}{ }^{3-}$ inorganic nutrient conditions, while accessing DOP and regenerated sources of $\mathrm{N}$ from $\mathrm{NH}_{4}{ }^{+}$and DON. These picocyanobacteria were able to outcompete competitors and grazers, and by accessing nutrient sources made available through biogeochemical processes, blooms able to be sustained for periods of months.

\section{Summary and implications}

Florida Bay has experienced a number of unique natural and anthropogenic stressors over the past decade, due to altered flow through the Everglades and a cascade of downstream biogeochemical changes which have resulted in seagrass die-offs and picocyanobacterial blooms. Increases in flow, combined with increased and episodic precipitation through storms and hurricanes, have increased the input of organic nutrients to Florida Bay in recent years (Shangguan et al. 2017a,b). This analysis has highlighted that salinity is a likely stressor when flows are low. However, when conditions of low flow and high salinity are followed by high flows with a high organic load (DON and DOP), hyper- $\mathrm{NH}_{4}{ }^{+}$conditions result. All of these conditions, in turn, contribute to the favorability of growth of picocyanobacterial relative to competing phytoplankton, such as diatoms. These relationships, some of which may typify lagoonal estuaries in general (Glibert et al. 2010), complicate management decisions regarding flow control. Viewing salinity control in isolation of other biogeochemical cascade and interactions may come at the cost of downstream algal bloom proliferation. Thus, efforts to restore water flow based on salinity criteria alone do not take into account the potential nutrient effects that come with increased water flow.

It is important to note that while this analysis has detailed the negative ecological effects of hurricanes and intense storms on the ecology of Florida Bay, 
there is an alternate perspective that pertains to the growth of surrounding mangrove wetlands. A recent report (Castañeda-Moya et al. 2020) suggest that the delivery of organic material and $\mathrm{P}$ from the storm surge (e.g., marine water input) following Hurricane Irma may have enhanced the $\mathrm{P}$ availability for mangroves. By providing a substantial supplement of $\mathrm{P}$ to the soil nutrient pool, these events may help to facilitate mangrove forest recovery. Although this may be considered a beneficial outcome of these event-scale disturbances, the trade-off may be largescale picocyanobacterial blooms down-bay.

Climate change and enhanced drought-intensive precipitation cycles will continue to enhance delivery of organic nutrients and material from the freshwaterEverglades source to this marine system, and conditions conducive for recurring picocyanobacterial blooms will continue. There is a scientific consensus that climate is changing and the overall intensity of storms will increase, even though their frequency may not (Woollings et al. 2012). Although enhanced efforts to reduce salinity and nutrient inputs will be important, the processes of marsh loss and sea level rise accompanying climate change will continue to simultaneously enhance organic nutrient export. Collectively, these changes will likely contribute to future episodic cycles of seagrass die-offs and algal blooms within Florida Bay.

Acknowledgements This synthesis was supported by awards from the South Florida Water Management Program to PMG, by the National Oceanic and Atmospheric Administration National Centers for Coastal Ocean Science Competitive Research Program (award number NA19NOS4780183) to PMG and $\mathrm{CAH}$, and by support from the Economos and Barancik Foundations to $\mathrm{CAH}$. The authors thank the reviewers for their comments. This is contribution number 5958 from the University of Maryland Center for Environmental Science and number ECO978 from the NOAA ECOHAB program. PMG wishes to thank Penny Johnes for the invitation to prepare this manuscript.

Author contributions CM and SK collected the primary data; PG and $\mathrm{CH}$ collected additional data. PG wrote the paper with the input of all authors.

Funding This synthesis was supported by awards from the South Florida Water Management Program to PMG, by the National Oceanic and Atmospheric Administration National Centers for Coastal Ocean Science Competitive Research Program (Award Number NA19NOS4780183) to PMG and $\mathrm{CAH}$, and by support from the Economos and Barancik Foundations to $\mathrm{CAH}$.
Data availability All data are available from the South Florida Water Management District or from the websites referenced in text.

\section{Compliance with ethical standards}

Conflicts of interest None.

Open Access This article is licensed under a Creative Commons Attribution 4.0 International License, which permits use, sharing, adaptation, distribution and reproduction in any medium or format, as long as you give appropriate credit to the original author(s) and the source, provide a link to the Creative Commons licence, and indicate if changes were made. The images or other third party material in this article are included in the article's Creative Commons licence, unless indicated otherwise in a credit line to the material. If material is not included in the article's Creative Commons licence and your intended use is not permitted by statutory regulation or exceeds the permitted use, you will need to obtain permission directly from the copyright holder. To view a copy of this licence, visit http://creativecommons.org/licenses/by/4.0/.

\section{References}

Abtew W, Trimble P (2010) El Niño-Southern Oscillation link to South Florida hydrology and water management applications. Wat Res Manag 24:4255-4271

Adams JB, Bate GC (1994) The tolerance to desiccation of the submerged macrophytes Ruppia cirrhosa (Petagna) Grande and Zostera capensis Setchell. J Exp Mar Biol Ecol 183:53-62. https://doi.org/10.1016/0022-0981(94)901562

Andersen JM (1974) Nitrogen and phosphorus budgets and the role of sediments in six shallow Danish lakes. Arch Hydrobiol 74:528-550

Apudo AA, Cao Y, Wakibia J, Li W, Liu F (2016) Physiological plastic responses to acute $\mathrm{NH}_{4}{ }^{+}-\mathrm{N}$ toxicity in Myriophyllum spicatum $\mathrm{L}$. cultured in high and low nutrient conditions. Environ Exper Bot 130:79-85. https://doi.org/10. 1016/j.envexpbot.2016.05.009

Aufdenkampe AK, Hedges JI, Richey JE, Krusche AV, Llerena CA (2001) Sorptive fractionation of dissolved organic nitrogen and amino acids onto fine sediments within the Amazon Basin. Limnol Oceanogr 46:1921-1935

Aufdenkampe AK, Mayorga E, Raymond PA, Melack JM, Doney SC, Alin SR, Aalto RE, Yoo K (2011) Riverine coupling of biogeochemical cycles between land, oceans, and atmosphere. Front Ecol Environ 9:53-60. https://doi. org/10.1890/100014

Bates NR, Astor YM, Church MJ, Currie K, Dore JE, GonzálezDávila M, Lorenzoni L, Muller-Karger F, Olafsson J, Santana-Casiano JM (2015) A time-series view of changing ocean chemistry due to ocean uptake of anthropogenic $\mathrm{CO}_{2}$ and ocean acidification. Oceanography 27(1):126-141. https://doi.org/10.5670/oceanogr.2014.16

Bench SR, Heller P, Frank I, Arciniega M, Shilova IN, Zehr JP (2013) Whole genome comparison of six Crocosphaera 
watsonii strains with different phenotypes. J Phycol 49:786-801. https://doi.org/10.1111/jpy.12090

Beusen AHW, Bouwman AF, Van Beek LPH et al (2016) Global riverine $\mathrm{N}$ and $\mathrm{P}$ transport to ocean increased during the 20th century despite increased retention along the aquatic continuum. Biogeosci 13:2441-2451

Biebl R, McRoy CP (1971) Plasmatic resistance and rate of respiration and photosynthesis of Zostera marina at different salinities and temperatures. Mar Biol 8:48-56. https://doi.org/10.1007/BF00349344

Boesch DF, Armstrong NE, D'Elia CF, Maynard NG, Paerl HW, Williams SL (1993) Deterioration of the Florida Bay ecosystem: an evaluation of the scientific evidence. Report to the Interagency Working Group on Florida Bay. Department of the Interior, National Park Service, Washington, DC

Boyer JN, Briceño HO (2008) FY2007 Annual report of the south Florida coastal water quality monitoring network. SERC Res Rep 16. https://digitalcommons/fiu.edu/sercrp/ 16.

Boyer JN, Fourqurean JW, Jones RD (1999) Seasonal and longterm trends in the water quality of Florida Bay (1989-1997). Estuaries 22:417-430

Boyer JN, Dailey SK, Gibson PJ, Rogers MT, Mir-Gonzalez D (2006) The role of dissolved organic matter bioavailability in promoting phytoplankton blooms in Florida Bay. Hydrobiologia 569:71-85. https://doi.org/10.1007/s10750006-0123-2

Briceño HO, Boyer JN (2010) Climatic controls on phytoplankton biomass in a sub-tropical estuary, Florida Bay, USA. Est Coasts 33:541-553

Britto DT, Kronzucker HJ (2002) $\mathrm{NH}_{4}{ }^{+}$toxicity in higher plants: a critical review. J Plant Physiol 159:567-584

Britto DT, Kronzucker HJ (2013) Ecological significance and complexity of $\mathrm{N}$-source preference in plants. Ann Bot 112:957-963

Brown JW (1987) Studies of humic and fulvic acid dynamics in coastal marine waters of South Floirda. Mar Envir Res 21:163-174. https://doi.org/10.1016/01411136(87)90063-8

Bushaw KL, Zepp RG, Tarr MA, Schulz-Janders D, Bourbonniere RA, Hodson RE, Miller WL, Bronk DA, Moran MA (1996) Photochemical release of biologically available nitrogen from aquatic dissolved organic matter. Nature 381:404-407

Bushaw-Newton KL, Moran MA (1999) Photochemical formation of biologically available nitrogen from dissolved humic substances in coastal marine systems. Aquat Microb Ecol 18:285-292

Cai W-J, Hu X, Huang W-J, Murrell MC, Lehrter JC, Lohrenz SE et al (2011) Acidification of subsurface coastal waters enhanced by eutrophication. Nat Geosci 4:766-770. https://doi.org/10.1038/ngeo1297

Cao T, Xie P, Ni L, Wu A, Zhang M, Wu S, Smolders AJP (2007) The role of $\mathrm{NH}_{4}{ }^{+}$toxicity in the decline of the submersed macrophyte Vallisneria natans in lakes of the Yangtze River basin, China. Mar Freshw Res 58:581-587

Cao T, Ni L, Xie P, Xu J, Zhang M (2011) Effects of moderate ammonium enrichment on three submersed macrophytes under contrasting light availability. Freshw Biol 56:1620-1629
Carlson PR, Yarbro LA, Kaufman KK, Mattson RA (2010) Vulnerability and resilience of west Florida seagrass communities to hurricane impacts. Hydrobiologia 649:39-53

Castañeda-Moya E, Rivera-Monroy VH, Chanbers RM, Zhao X, Lamb-Wotton L, Gorsky A, Gaiser EE, Troxler TG, Komonoski JS, Hiatt M (2020) Hurricanes fertilizer mangrove forests in the Gulf of Mexico (USA). Proc Natl Acad US 117:4831-4841. https://doi.org/10.1073/pnas. 19085977117

Chen M, Price RM, Yamashita Y, Jaffé R (2010) Comparative study of dissolved organic matter from groundwater and surface water in the Florida coastal Everglades using multidimensional spectrofluorometry combined with multivariate statistics. Appl Geochem 25:872-880. https://doi.org/ 10.1016/j.apgeochem.2010.03.005

Cochlan WP, Bronk DA (2003) Effects of ammonium on nitrate utilization in the Ross Sea, Antarctica: implications for f-ratio estimates. In DiTullio GR, Dunbar RB (Eds), Biogeochemistry of the Ross Sea. AGU Antarctic Research Series, Vol 78, AGU Publications. Washington DC, p. $159-178$.

Cochlan WP, Harrison PJ (1991) Inhibition of nitrate uptake by ammonium and urea in the eukaryotic picoflagellate $\mathrm{Mi}$ cromonas pusilla (Butcher) Manton et Parke. J Exp Mar Biol Ecol 153:143-152

Cole JJ, Caraco NF, Kling GW, Kratz TK (1994) Carbon dioxide supersaturation in the surface waters of lakes. Science 265:1568-1580. https://doi.org/10.1126/science. 265.5178.1568

Collier CJ, Villacorta-Rath C, van Dijk K-J, Takahashi M, Waycott M (2014) Seagrass proliferation precedes mortality during hyposalinity events: a stress-induced morphometric response. PLoS ONE 9:e94014. https://doi.org/ 10.1371/journal.pone.0094014

Collos Y, Harrison PJ (2014) Acclimation and toxicity of high ammonium concentrations to unicellular algae. Mar Poll Bull 80:8-23

Clinton PW, Newman RH, Allen RB (1995) Immobilization of ${ }^{15} \mathrm{~N}$ in forest litter studied by ${ }^{15} \mathrm{~N}$ CPMAS NMR spectroscopy. Eur J Soil Sci 46:551-556

Dagg, MJ, Ortner P. (1996). Zooplankton abundance and grazing potential in Florida Bay. Florida Bay Science Conference, p. 30-31. University of Florida and Sea Grant of Florida

Damashek J, Francis CA (2018) Microbial nitrogen cycling in estuaries: from genes to ecosystem processes. Est Coasts 41:626-660. https://doi.org/10.1007/s12237-017-0306-2

Dortch Q (1990) The interaction between ammonium and nitrate uptake in phytoplankton. Mar Ecol Prog Ser 61:183-201

Drake JC, Heaney SI (1987) Occurrence of phosphorus and its potential remobilization in the littoral sediments of a productive English lake. Freshwat Biol 17:513-523

Duarte CM, Hendriks IE, Moore TS, Olsen YS, Steckbauer A, Ramajo L et al (2013) Is ocean acidification an open-ocean syndrome? Understanding anthropogenic impacts on seawater pH. Est Coast 36:221-236. https://doi.org/10.1007/ s12237-013-9594-3

Duever MJ, Meeder JF, Meeder LC, McCollom JM (1994) The climate of south Florida and its role in shaping the Everglades ecosystem. In: Davis S, Ogden J (eds) Everglades: 
the ecosystem and its restoration. St. Lucie Press, Boca Raton, pp 225-248

Dugdale RC, Wilkerson FP, Hogue VE, Marchi A (2007) The role of ammonium and nitrate in spring bloom development in San Francisco Bay. Est Coast Shelf Sci 73:17-29

Dugdale RC, Wilkerson FP, Parker AE, Marchia A, Taberski K (2012) River flow and ammonium discharge determine spring phytoplankton blooms in an urbanized estuary. Est Coast Shelf Sci 115:187-199

Durako MJ, Hall MO, Merello M (2002) Patterns of change in the seagrass dominated Florida Bay hydroscape. In: Porter JW, Porter KG (eds) The Everglades, Florida Bay and coral reefs of the Florida Keys, an ecosystem sourcebook. CRC Press, Boca Raton, pp 523-537

Dyhrman ST, Haley ST (2006) Phosphorus scavenging in the unicellular marine diazotroph Crocosphaera watsonii. Appl Envir Microbiol 72:1452-1458

Easterling DR, Meehl GA, Parmesan C, Changnon SA, Karl TR, Mearns LO (2000) Climate extremes: Observations, modeling, and impacts. Science 289:2068-2074

Engel V (2012) Sea-level rise compounds the uncertainties facing the future of mangrove habitats. In: Krucynski WL, Fletcher PJ (eds) Tropical connections: South Florida's marine environment. IAN Press, University of Maryland Center for Environmental Science, Cambridge MD, p 324

Enochs IC, Manzello DP, Jones PR, Stamates SJ, Carsey TP (2019) Seasonal carbonate chemistry dynamics on southeast Florida coral reefs: localized acidification hotsptos from navigational inlets. Fron Mar Sci. https://doi.org/10. 3389/fmars.2019.00160

Fernández-Torquemada Y, Sánchez-Lizaso JL (2011) Responses of two Mediterranean seagrasses to experimental changes in salinity. Hydrobiol 669:21. https://doi.org/10. 1007/s10750-011-0644-1

Fourqurean JW, Robblee MB (1999) Florida Bay: a history of recent ecological changes. Estuaries 22:345-357

Fourqurean JW, Rutten LM (2004) The impact of Hurricane Georges on soft-bottom, back reef communities: site-and species-specific effects in south Florida seagrass beds. Bull Mar Sci 75:239-257

Fourqurean JW, Zieman JC, Powell GVN (1992) Phosphorus limitation of primary production in Florida Bay: evidence from C:N: P ratios of the dominant seagrass Thalassia testidinum. Limnol Oceanogr 37:162-171

Fourqurean JW, Jones RD, Zieman JC (1993) Processes influencing water column nutrient characteristics and phosphorus limitation of phytoplankton biomass in Florida Bay, FL, USA: inferences from spatial distributions. Estuar Coast Shelf Sci 36:295-314

Fourqurean JW, Durako MJ, Hall MO, Hefty LN (2002) Seagrass distribution in south Florida: A multi-agency coordinated monitoring program. In: Porter JW, Porter KG (eds) The Everglades, Florida Bay and coral reefs of the Florida Keys, an ecosystem sourcebook. CRC Press, Boca Raton, pp 497-522

Frankovich TA, Morrison D, Fourqurean JW (2011) Benthic macrophyte distribution and abundance in estuarine mangrove lakes and estuaries: Relationships to environmental variables. Est Coast 34:20-31. https://doi.org/10.1007/ s12237-010-9279-0
Fu Z, Wu F, Song K, Lin Y, Bai Y, Zhu Y (2013) Competitive interaction between soil-derived humic acid and phosphate on goethite. Appl Geochem 36:125-131

Gao Y, Cornwell JC, Stoecker DK, Owens MS (2012) Effects of cyanobacterial driven $\mathrm{pH}$ increases on sediment nutrient fluxes and coupled nitrification-denitrification in a shallow fresh water estuary. Biogeosci 9:2697-2710

Gardner WS, McCarthy MJ (2009) Nitrogen dynamics at the sediment-water interface in shallow, sub-tropical Florida Bay: why denitrification efficiency may decrease with eutrophication. Biogeochem 95:185-198

Garrote-Moreno A, Sandoval-Gil JM, Ruiz JM, Marín-Guirao L, Bernardeau-Esteller J, Muñoz RJ, Sánchez Lizaso JL (2015) Plant water relations and ion homeostasis of Mediterranean seagrasses (Posidonia oceanica and Cymodocea nodosa) in response to hypersaline stress. Mar Biol 162:55-68. https://doi.org/10.1007/s00227-014-2565

Glibert PM (2020) Harmful algae at the complex nexus of eutrophication and climate change. Harmful Algae. https:// doi.org/10.1016/j.hal.2019.03.001

Glibert PM, Burkholder JM (2011) Eutrophication and HABs: Strategies for nutrient uptake and growth outside the Redfield comfort zone. Chin J Oceanol Limnol 29:724-738

Glibert PM, Heil CA, Hollander D, Revilla M, Hoare A, Alexander J, Murasko S (2004) Evidence for dissolved organic nitrogen and phosphorus uptake during a cyanobacterial bloom in Florida Bay. Mar Ecol Prog Ser 280:73-83. https://doi.org/10.3354/meps280073

Glibert PM, Heil CA, Rudnick DT, Madden CJ, Beach WP, Boyer JN, Kelly SP (2009) Florida Bay: Water quality status and trends, historic and emerging algal bloom problems. Contrib Mar Sci 38:5-17

Glibert PM, Boyer JN, Heil CA, Madden CJ, Sturgis B, Wazniak CS (2010) Blooms in lagoons: different from those of riverdominated estuaries. In: Kennish MJ, Paerl HW (eds) Coastal Lagoons: critical habitats of environmental change. CRC Press Taylor and Francis Group, Boca Raton, pp 91-113

Glibert PM, Fullerton D, Burkholder JM, Cornwell JC, Kana TM (2011) Ecological stoichiometry, biogeochemical cycling, invasive species, and aquatic food webs: San Francisco Estuary and comparative systems. Rev Fish Sci 19:358-417. https://doi.org/10.1080/10641262.2011. 611916

Glibert PM, Manager R, Sobota DJ et al (2014) The HaberBosch-Harmful algal bloom (HB-HAB) link. Environ Res Lett 9:105001. https://doi.org/10.1088/1748-9326/9/10/ 105001

Glibert PM, Wilkerson FP, Dugdale RC, Raven JA, Dupont CL, Leavitt PR, Parker AE, Burkholder JM, Kana TM (2016) Pluses and minuses of ammonium and nitrate uptake and assimilation by phytoplankton and implications for productivity and community composition, with emphasis on nitrogen-enriched conditions. Limnol Oceanogr 61:165-197

Glibert PM, Beusen AHW, Harrison JA, Dürr HH, Bouwman A, Laruelle GG (2018) Changing land, sea- and airscapes: Sources of nutrient pollution affecting habitat suitability for harmful algae. In: Glibert PM, Berdalet E, Burford M, Pitcher G, Zhou M (eds) Ecology and oceanography of 
harmful algal blooms (GEOHAB). Springer, Cham, pp 53-76

Glibert PM, Beusen AHW, Bouwman AF, Burkholder JM, Flynn KJ, Heil CA, Li M, Lin C-H, Madden CJ, Mitra A, Nardin W, Silsbe G, Song Y, Zhang F. (2020). Multifaceted climatic change and nutrient effects on harmful algae require multifaceted models. In: Botana LM, C. Louzao and N. Vilariño (Eds), Climate change and marine and freshwater toxins, 2nd edition. DeGruyter Publishers.https://doi.org/10.1515/9783110625738-012.

Granéli W (2012) Brownification of lakes. In: Bengtsson L, Herschy RW, Fairbridge RW (eds) Encyclopedia of lakes and reservoirs. Springer, Dordrecht, pp 117-119

Grill G, Lehner B, Lumsdon AE et al (2015) An index-based framework for assessing patterns and trends in river fragmentation and flow regulation by global dams at multiple scales. Environ Res Lett 10:015001

Grillo JF, Gibson J (1979) Regulation of phosphate accumulation in the unicellular cyanobacterium Synechococcus. J Bacteriol 140:508-517

Grossman AR (1991) Isolation, transcription and inactivation of the gene for an atypical alkaline phosphatase of Synechococcus sp. strain PCC7942. J Bacteriol 173:4297-4309

Hagedorn F, Schleppi P, Waldner P, Flühler H (2000) Export of dissolved organic carbon and nitrogen from Gleysol dominated catchments - the significance of water flow paths. Biogeochem 50:137-161

Hall MO, Durako MJ, Fourqurean JW, Zieman JC (1999) Decadal changes in seagrass distribution and abundance in Florida Bay. Estuaries 22:445-459

Hampel JJ, McCarthy MJ, Aalto SI, Newell SE (2020) Hurricane disturbance stimulated nitrification and altered ammonia oxidizer community structure in Lake Okeechobee and St Lucie Estuary (Florida). Frontiers in Microbiol. https://doi.org/10.3389/fmicb.2020.01541

Heil CA, Glibert PM, Murasko S, Alexander J (2009) Sizefractioned alkaline phosphatase activity along a gradient of nitrogen to phosphorus limitation in a carbonate dominated subtropical estuary. Contr Mar Sci 38:37-48

Hitchcock GL, Vargo GA, Forccuci D, Ortner PB (1998) Phytoplankton biomass in Florida Bay, June 1998-July 1999. In Brock RJ (Ed) State of the Bay, the condition of Florida Bay in 1998. National Park Service SFNRC Tech Rep, Homestead, FL, pp 13-16

Hoer DR, Sharp W, Delgado G, Lindquist NL, Martens CS (2020) Sponges represent a major source of inorganic nitrogen in Florida Bay (USA). Limnol Oceanogr 65:1235-1250

Hofmann GE, Smith JE, Johnson KS, Send U, Levin LA, Micheli F, Paytan A et al (2011) High-freqency dynamics of ocean $\mathrm{pH}$ : a multi-ecosystem comparison. PLoS ONE. https://doi.org/10.1371/journal.pone.0028983

Hollander GM (2008) Raising cane in the 'glades: the global sugar trade and the transformation of Florida. University of Chicago Press, Chicago, p 348

Hornberger GM, Bencala KE, McKnight DM (1994) Hydrological controls on dissolved organic carbon during snowmelt in the Snake River near Montezuma, Colorado. Biogeochem 25:147-165
Howarth RW (2008) Coastal nitrogen pollution: A review of sources and trends globally and regionally. Harmful Algae 8:14-20

Huesemann MH, Skillman AD, Crecelius EA (2002) The inhibition of marine nitrification by ocean disposal of carbon dioxide. Mar Pollut Bull 44:142-148

Hunt J, Nuttle, W, eds. (2007) Florida Bay Science Program: A synthesis of research on Florida Bay. Fish and Wildlife Research Institute Technical Report Florida Fish and Wildlife Research Institute, St. Petersburg, FL, 148 pp.

Jensen HS, Andersen FO (1992) Importance of temperature, nitrate, and $\mathrm{pH}$ for phosphate release from sediments of four shallow, eutrophic lakes. Limnol Oceanogr 39:577-589

Johnson CR, Koch MS, Pedersen O, Madden CJ (2018) Hypersalinity as a trigger of seagrass (Thalassia testudinum) die-off events in Florida Bay: evidence based on shoot meristem $\mathrm{O}_{2}$ and $\mathrm{H}_{2} \mathrm{~S}$ dynamics. J Exp Mar Biol Ecol 504:47-52

Julian P (2020) Getting the science right to protect and restore our environment. A critique of Lapointe et al. (2019) Nitrogen enrichment, altered stoichiometry, and coral reef decline at Looe Key, Florida Keys, USA: a 3-decade study. Mar Biol 167:1-9

Kamermans P, Hemminga MA, de Jong DJ (1999) Significance of salinity and silicon levels for growth of a formerly estuarine eelgrass (Zostera marina) population (Lake Grevelingen, The Netherlands). Mar Biol 133:527-539

Kelble CR, Johns EM, Nuttle WK, Lee TN, Smith RH, Ortner PB (2007) Salinity patterns of Florida Bay. Est Coast Shelf Sci 71(2007):318-334

Kemp WM, Boynton WR, Adolf JE, Boesch DF, Boicourt WC, Brush G, Cornwell JC, Fisher TR, Glibert PM, Hagy JD, Harding LW, Houde ED, Kimmel DG, Miller WD, Newell RIE, Roman MR, Smith EM, Stevenson JC (2005) Eutrophication in Chesapeake Bay: historical trends and ecological interactions. Mar Ecol Prog Ser 303:1-29

Kirk JTO (2011) Light and photosynthesis in aquatic ecosystems, 3rd edn. Cambridge University Press, Cambridge

Knutson TR, Tuleya RE (2004) Impact of $\mathrm{CO}_{2}$-induced warming on simulated hurricane intensity and precipitation: sensitivity to the choice of climate model and convective parameterization. J Climate 17:3477-3495

Kobelt JN, Sharp WC, Miles TN, Feehan CJ (2019) Localized impacts of Hurricane Irma on Diadema antillarum and coral reef community structure. Est Coasts 43:1133-1142. https://doi.org/10.1007/s12237-019-00665-4

Koch MS, Benz RE, Rudnick DT (2001) Solid phase phosphorus pools in highly organic carbonate sediments of northeastern Florida Bay. Est Coast Shelf Sci 52:279-291

Koch MS, Schopmeyer SA, Nielsen OI, Kyhn-Hansen C, Madden CJ (2007) Conceptual model of seagrass die-off in Florida Bay: links to biogeochemical processes. J Exp Mar Biol Ecol 350:73-88

Koch MS, Kletou DC, Tursi R (2009) Alkaline phosphatase activity of water column fractions and seagrass in a tropical carbonate estuary, Florida Bay. Est Coast Shelf Sci. https:// doi.org/10.1016/j.ecss.2009.04.007

Korosh TC, Dutcher A, Pfleger BF, McMahon KD (2018) Inhibition of cyanobacterial growth on a municipal wastewater sidestream is impacted by temperature. 
mSphere 3:e00538. https://doi.org/10.1128/mSphere. 00538-17

Kudela RM, Dugdale RC (2000) Nutrient regulation of phytoplankton productivity in Monterey Bay, California. DeepSea Res Part II 47:1023-1053

Lagomasino D, Fatoyinbo T, Castañeda-Moya E, Cook B, Montesano P, Neigh C, Ott L, Chavez S, Morton D (2020) Storm surge, not wind, caused mangrove dieback in southwest Florida following Hurricane Irma. EarthArXiv. https://doi.org/10.31223/osf.io/q4exh

Lapointe BE, Barile PJ (2004) Comment on JC Zieman, JW Fourqurean, and TA Frankovich. 1999. Seagrass dieoff in Florida Bay: Long-term trends in abundance and growth of turtle grass. Estuaries 27:157-178. https://doi.org/10.1007/ BF02803569

Lapointe BE, Clark MW (1992) Nutrient inputs from the watershed and coastal eutrophication in the Florida Keys. Estuaries 15:465-476

Lapointe BE, Brewton RA, Herren LW, Porter JW, Hu C (2019) Nitrogen enrichment, altered stoichiometry, and coral reef decline at Looe Key, Florida Keys, USA: a 3-decade study. Mar Biol 166:108. https://doi.org/10.1007/s00227-0193538-9

Lapointe BE, Brewton RA, Herren LW, Porter JW, Hu C, Cannizzaro JP (2020) Sound science, not politics, must inform restoration of Florida Bay and the coral reefs of the Florida Keys. Mar Biol 167:1-12. https://doi.org/10.1007/ s00227-020-3669-z

Lavrentyev PJ, Bootsma HA, Johengen TH, Cavaletto JF, Gardner WS (1998) Microbial plankton response to resource limitation: insights from the community structure and seston stoichiometry in Florida Bay, USA. Mar Ecol Prog Ser 165:45-57

Lee E, Glover CM, Rosario-Ortiz FL (2013) Photochemical formation of hydroxyl radical from effluent organic matter: Role of composition. Environ Sci Technol 47:12073-12080. https://doi.org/10.1021/es402491t

Lee TN, Johns E, Ortner P (2007) Physical processes. In Hunt JH, Nuttle W (Eds.), Florida Bay science program: a synthesis of research on Florida Bay. Florida Fish and Wildlife Conservation Institute, pp 30-54

Lee TN, Johns E, Melo N, Smith RH, Ortner P, Smith D (2006) On Florida Bay hypersalinity and water exchange. Bull Mar Sci 79:301-327

Lee TN, Melo N, Johns E, Kelble C, Smith RH, Ortner P (2008) On water renewal and salinity variability in the northeast subregion of Florida Bay. Bull Mar Sci 82:83-105

L'Helguen S, Maguer J-F, Caradec J (2008) Inhibition kinetics of nitrate uptake by ammonium in size-fractionated oceanic phytoplankton communities: implications for new production and $f$-ratio estimates. $\mathrm{J}$ Plankt Res 10:1179-1188

Li H, Veldhuis MJW, Post AF (1998) Alkaline phosphatase activities among planktonic communities in the northern Red Sea. Mar Ecol Prog Ser 173:107-115

Madden C (2010) Florida Bay. In Glibert PM, Madden CJ, Boynton W, Flemer D, Heil C, Sharp J (Eds), Nutrients in estuaries: a summary report of the National Estuarine Experts Workgroup, 2005-2007. US EPA, Office of Water, pp. 155-166. https://19january2017snapshot.epa.gov/sites/ production/files/documents/nutrients-in-estuariesnovember-2010.pdf.

Madden C, Day J (1992) An instrument system for high-speed mapping of chlorophyll a and physico-chemical variables in surface waters. Estuaries. https://doi.org/10.2307/ 1352789

Marshall FE, Bernhardt CE, Wingard GL (2020). Estimating late $19^{\text {th }}$ century hydrology in the Greater Everglades Ecosystem: an integration of paleoecological data and models. Front Environ Sci doi: https://doi.org/10.3389/ fenvs.2020.00003

Marzetz V, Spijkerman E, Striebel M, Wacker A (2020) Phytoplankton community responses to interactions between light intensity, light variations, and phosphorus supply. Front Envir Sci 8:539733. https://doi.org/10.3389/fenvs. 2020.539733

Massotti I, Aparicio-Rizzo P, Yevenes MA, Garreaud R, Belmar L, Farías L (2018) The influence of river discharge on nutrient export and phytoplankton biomass off the central Chile coast $\left(33^{\circ}-37^{\circ} \mathrm{S}\right)$ : seasonal cycle and interannual variability. Front Mar Sci. https://doi.org/10.3389/fmars. 2018.00423

McIvor CC, Ley JA, Bjork RD (1994) Changes in freshwater inflow from the Everglades to Florida Bay including effects on biota and biotic processes: a review. In: Davis S, Ogden J (eds) Everglades: the ecosystem and its restoration. St Lucie Press, Boca Raton, pp 117-146

Millero FJ, Hiscock WT, Huang F, Roche M, Zhang JZ (2001) Seasonal variation of the carbonate system in Florida Bay. Bull Mar Sci 68:101-123

Montagne P, Palmer TA, Pollack JB (2012) Hydrological changes and estuarine dynamics. Springer. https://doi.org/ 10.1007/978-1-4614-5833-3

Nielsen O, Koch MS, Jensen HS, Madden CJ (2006) Thalassia testudinum phosphate uptake kinetics at low in situ concentrations using a ${ }^{33} \mathrm{P}$ radioisotope technique. Limnol Oceanogr 51:208-217

Nimptsch J, Pflugmacher S (2007) Ammonia triggers the promotion of oxidative stress in the aquatic macrophyte Myriophyllum mattogrossense. Chemosphere 66:708-714

Ogata E, Matsui T (1965) Photosynthesis in several marine plants of Japan as affected by salinity, drying and $\mathrm{pH}$, with attention to their growth habitats. Bot Mar 8:199-217. https://doi.org/10.1515/botm.1965.8.2-4.199

O'Neil JM, Davis TW, Burford MA, Gobler CJ (2012) The rise of harmful cyanobacteria blooms: the potential roles of eutrophication and climate change. Harmful Algae 14:313-334

Paerl HW, Huisman J (2009) Climate change: a catalyst for global expansion of harmful cyanobacterial blooms. Environ Microbiol Rep 1:27-37

Paerl HW, Paul VJ (2012) Climate change: links to global expansion of harmful cyanobacteria. Wat Res 46:1349-1363

Peierls BL, Christian RR, Paerl HW (2003) Water quality and phytoplankton as indicators of hurricane impacts on a large estuarine ecosystem. Estuaries 26:1329-1343

Perassi I, Borgnino L (2014) Adsorption and surface precipitation of phosphate onto $\mathrm{CaCO}_{3}$-montmorillonite: effect of $\mathrm{pH}$, ionic strength and competition with humic acid. Geoderma 232-234:600-608 
Phlips EJ, Badylak S (1996) Spatial variability in phytoplankton standing crop and composition in a shallow inner-shelf lagoon, Florida Bay, Florida. Bull Mar Sci 58:203-216

Phlips EJ, Badylak S, Lynch TC (1999) Blooms of the picoplanktonic cyanobacterium Synechococcus in Florida Bay, a subtropical inner-shelf lagoon. Limnol Oceanogr 44:1166-1175

Phlips EJ, Badylak S, Lasi MA, Chamberlain R, Green WC, Hall LM, Hart JA, Lockwood JC, Miller JD, Morris LJ, Steward JS (2014) From red tides to green and brown tides: bloom dynamics in a restricted subtropical lagoon under shifting climatic conditions. Est Coasts. https://doi.org/10.1007/ s12237-014-9874-6

Phlips EJ, Badylak S, Nelson NG, Havens KE (2020) Hurricanes, El Niño and harmful algal blooms in two sub-tropical Florida estuaries: direct and indirect impacts. Sci Rep 10:1910. https://doi.org/10.1038/s41598-020-58771-4

Piro A, Marín-Guirao L, Serra IA, Spadafora A, Sandoval-Gil JM, Bernardeau-Esteller J et al (2015) The modulation of leaf metabolism plays a role in salt tolerance of Cymodocea nodosa exposed to hypersaline stress in mesocosms. Front Plant Sci 6:464. https://doi.org/10.3389/fpls.2015.00464

Powell GV, Kenworthy JW, Fourqurean JW (1989) Experimental evidence for nutrient limitation of seagrass growth in a tropical estuary with restricted circulation. Bull Mar Sci 44:324-340

Preece EP, Hardy FJ, Moore BC, Bryan M (2017) A review of microcystin detections in estuarine and marine waters: environmental implications and human health risk. Harmful Algae 61:31-45

Qualls RG, Richardson CJ (2003) Factors controlling concentration, export, and decomposition of dissolved organic nutrients in the Everglades of Florida. Biogeochem 2:197-229

Raven JA (1998) The twelfth Tansley lecture. Small is beautiful: the picophytoplankton. Funct Ecol 12:503-513. https://doi. org/10.1046/j.1365-2435.1998.00233.x

Raven JA, Wollenweber B, Handley LL (1992) A comparison of ammonium and nitrate as nitrogen sources for photolithotrophs. New Phytol 121:19-32

Ray JM, Bhaya D, Block MA, Grossman AR (1991) Isolation, transcription and inactivation of the gene for an atypical alkaline phosphatase of Synechococcus sp strain PCC7942. J Bacteriol 173:4297

Richardson LL, Zimba PV (2002) Spatial and temporal patterns of phytoplankton in Florida Bay: utility of algal accessory pigments and remote sensing to assess bloom dynamics. In: Porter JW, Porter KG (eds) The everglades, Florida Bay and coral reefs of the Florida Keys, an ecosystem sourcebook. CRC Press, Boca Raton, pp 461-478

Robblee M, Barber TR, Carlson PR, Durako MJ, Fourqurean JW, Muehlstein LK, Porter D, Yarbro LA, Zieman RT, Zieman JC (1991) Mass mortality of the tropical seagrass Thalassia testudinum in Florida Bay (USA). Mar Ecol Prog Ser 71:297-299. https://doi.org/10.3354/meps071297

Sandoval-Gil JM, Marín-Guirao L, Ruiz JM (2012) The effect of salinity increase on the photosynthesis, growth and survival of the Mediterranean seagrass Cymodocea nodosa. Est Coast Shelf Sci 115:260-271. https://doi.org/10.1016/j. ecss.2012.09.008
Sandoval-Gil JM, Ruiz JM, Marín-Guirao L, BernardeauEsteller J, Sánchez-Lizaso JL (2014) Ecophysiological plasticity of shallow and deep populations of the Mediterranean seagrasses Posidonia oceanica and Cymodocea nodosa in response to hypersaline stress. Mar Envir Res 95:39-61. https://doi.org/10.1016/j.marenvres. 2013.12.011

Scanlan DJ, Ostrowski M, Mazard S, Dufresne A, Garczarek L, Hess WR, Post AF, Hagemann M, Paulsen I, Partensky F (2009) Ecological genomics of marine picocyanobacterial. Microbiol Mol Biol Rev 73:249-299. https://doi.org/10. 1128/MMBR.00035-08

Schmidt N, Luther ME (2002) ENSO impacts on salinity in Tampa Bay, Florida. Estuaries 25:976-984

Schmidt N, Lipp KE, Rose JB, Luther ME (2001) ENSO influences on seasonal rainfall and river discharge in Florida. J Climate 14:615-628

See J, Bronk DA, Lewitus AJ (2006) Uptake of Spartina-derived humic nitrogen by estuarine phytoplankton in nonaxenic and axenic culture. Limnol Oceanogr 51:2290-2299

Seitzinger SP (1991) The effect of $\mathrm{pH}$ on the release of phosphorus from Potomac Estuary sediments: implications for blue-green algal blooms. Est Coast Shelf Sci 33:409-418

Seitzinger SP, Mayorga E, Bouwman AF et al (2010) Global river nutrient export: a scenario analysis of past and future trends. Glob Biogeochem Cycles 24:8. https://doi.org/10. 1029/2009GB003587

Shangguan Y, Glibert PM, Alexander JA, Madden CJ, Murasko S (2017a) Nutrients and phytoplankton community composition in semi-enclosed lagoon systems in Florida Bay and their responses to changes in flow from Everglades restoration. Limnol Oceanogr 62:S327-S347. https://doi. org/10.1002/lno.10599

Shangguan Y, Glibert PM, Alexander JA, Madden CJ, Murasko S (2017b) Phytoplankton community response to changing nutrients in Florida Bay: results of mesocosm studies. J Exp Mar Biol Ecol 494:38-53. https://doi.org/10.1016/j.embe. 2017.05.006

South Florida Water Management District (SFWMD) (2015a) Chemistry Laboratory Quality Manual. SFWMD-LABQM-2015-01, South Florida Water Management District, West Palm Beach, FL.

South Florida Water Management District (SFWMD) (2015b) Field Sampling Quality Manual. SFWMD-FIELD-QM001-08, South Florida Water Management District, West Palm Beach, FL.

Stumpf RP, Frayer ML, Durako MJ, Brock JC (1999) Variations in water clarity and bottom albedo in Florida Bay from 1985-1997. Estuaries 22:431-444

Tank SE, Lesack LFW, McQueen DJ (2009) Elevated pH regulates carbon cycling in lakes with high photosynthetic activity. Ecology 90:1910-1922

Timko SA, Romera-Castillo C, Jaffé R, Cooper WJ (2014) Photo-reactivity of natural dissolved organic matter from fresh to marine waters in the Florida Everglades, USA. Envir Sci 16:866-878. https://doi.org/10.1039/ C3EM00591G

Tonk L, Bosch K, Visser PM, Huisman J (2007) Salt tolerance of the harmful cyanobacterium Microcystis aeruginosa. Aquat Microb Ecol 46:117-123 
Touchette B (2007) Seagrass-salinity interactions: physiological mechanisms used by submersed marine angiosperms for a life at sea. J Exp Mar Biol 350:194-215. https://doi. org/10.1016/j.jembe.2007.05.037

Urrutia-Corderoct P, Ekvall MK, Hansson L-A (2016) Local food web management increases resilience and buffers against global change effects on freshwaters. Sci Rep 6:29542. https://doi.org/10.1038/srep29542.2006)

Urrutia O, Erro J, Guardado I, San Francisco S, Mandado M, Baigorri R, Yvin JC, Garcia-Mina J (2014) Physicochemical characterization of humic-metal-phosphate complexes and their potential application to the manufacture of new types of phosphate-based fertilizers. J Plant Nutr Soil Sci 177:128-136

van Katwijk MM, Schmitz GHW, Gasseling AM, van Avesaath PH (1999) The effects of salinity and nutrient load and their interaction on Zostera marina L. Mar Ecol Progr Ser 190:155-165

Van Mooy BAS, Rocap G, Fredricks HF, Evans CT, Devol AH (2009) Sulfolipids dramatically decrease phosphorus demand by picocyanobacterial in oligotrophic marine environments. Proc Natl Acad Sci US 103:8607-8612. https://doi.org/10.1073/pnas.0600540103

Vicente-Serrano SM, Peña-Gallardo M, Hannaford J et al (2019) Climate, irrigation, and land cover change explain streamflow trends in countries bordering the northeast Atlantic. Geophy Res Letts https://doi.org/10.1029/ 2019GL084084

Wachnicka A, Browder J, Jackson T, Louda W, Kelble C, Abdelrahman O, Stabenau E, Avila C (2019) Hurricane Irma's impact on water quality and phytoplankton communities in Biscayne Bay (Florida, USA). Est Coasts. https://doi.org/10.1007/s12237-019-00592-

Wagner K-U, Masepohl B, Pistorius EK (1995) The cyanobacterium Synechococcus sp. strain PCC 7942 contains a second alkaline phosphatase encode by phoV. Microbiol 141:3049-3058

Wallace RB, Baumann H, Grear JS, Aller RC, Gobler CJ (2014) Coastal ocean acidification: the other eutrophication problem. Est Coast Shelf Sci 148:1-13. https://doi.org/10. 1016/j.ecss.2014.05.027

Wang H, Zhu J, Fu Q, Hong C, Hu H, Violante A (2016) Phosphate adsorption on uncoated and humic acid-coated iron oxides. J Soils Sed 16:1911-1920

Wanless H, Krucynski WL, Fletcher PJ. (2012). Climate change will have several potential impacts to South Florida. In: Krucynski WL, Fletcher, PJ (eds.) Tropical Connections: South Florida's Marine Environment. IAN Press, University of Maryland Center for Environmental Science. p. 35. http://ian.umces.edu/press/books/publication/374/ tropical_connections_south_florida_s_marine_ environment_2012-07-02/

Wilkerson FP, Dugdale RC, Kudela RM, Chavez FP (2000) Biomass and productivity in Monterey Bay, California: contribution of the large phytoplankton. Deep-Sea Res Part II 47:1003-1022. https://doi.org/10.1016/ S09670645(99)00135-6

Wilson B, Servais S, Mazzei V, Kominoski JS, Hu M et al (2018) Salinity pulses interact with seasonal dry-down to increase ecosystem carbon loss in marshes of the Florida
Everglades. Ecol Appl 28:2092-2108. https://doi.org/10. 1002/eap.1798

Wilson SS, Furman BT, Hall MO, Fourqurean JW (2020) Assessment of Hurricane Irma impacts on South Florida seagrass communities using long-term monitoring programs. Est Coasts 43:1119-1132

Williamson CE, Overholt EP, Pilla RM, Leach TH, Brentrup JA, Knoll LB, Mette EM, Moeller RE (2015) Ecological consequences of long-term browning of lakes. Sci Rep 5:18666. https://doi.org/10.10138/srep18666

Witman S (2018) Impact of hurricanes and nor'easters on coastal forests. EOS 99(8):40

Woollings T, Gregory JM, Pinto JG, Reyers M, Brayshaw DJ (2012) Response of the North Atlantic storm track to climate change shaped by ocean-atmosphere coupling. Nat Geosci 5:313-317. https://doi.org/10.1038/NGEO1438

Xie LQ, Xie P, Tang HJ (2003) Enhancement of dissolved phosphorus release from sediment to lake water by $\mathrm{Mi}$ crocystis blooms - an enclosure experiment in a hypereutrophic, subtropical Chinese lake. Envir Poll 122:391-399

Yang J, Gao H, Glibert PM, Wang Y, Tong M (2017) Rates of nitrogen uptake by cyanobacterially-dominated assemblages in Lake Taihu, China, during late summer. Harmful Algae 65:71-84. https://doi.org/10.1016/j.hal.2017.04.001

Ye S, Covn TP, Sivapalan M, Basu NB, Li H-Y, Wang S-W (2012) Dissolved nutrient retention networks: a modeling investigation of transient flows and scale effects. Wat Res Res. https://doi.org/10.1029/2011WR010508

Zarfl C, Lumsdon AE, Berlekamp J et al (2015) A global boom in hydropower dam construction. Aquatic Sci 77:161-170

Zhang D, Yan S, Song W (2014) Photochemically induced formation of reactive oxygen species (ROS) from effluents organic matter. Environ Sci Technol 48:12645-12653. https://doi.org/10.1021/es5028663

Zheng Z-Z, Wan X, Xu MN, Hsiao SS-Y, Zhang Y, Zheng L-W, Wu Y, Zou W, Kao S-J (2017) Effects of temperature and particles on nitrification in a eutrophic coastal bay in southern China. JGR Biogeosci. https://doi.org/10.1002/ 2017JG003871

Zhou Q, Gao J, Zhang Rm Zhang R (2017) Ammonia stress on nitrogen metabolism in tolerant aquatic plant-Myriophyllum aquaticum. Ecotox Envir Saf 143:102-110. https://doi. org/10.1016/j.ecoenv.2017.04.016

Zieman JC (1975) Seasonal variation of turtle grass, Thalassia testudinum König, with reference to temperature and salinity effects. Aquat Bot 1:107-123. https://doi.org/10. 1016/0304-3770(75)90016-9

Zieman JC, Fourqurean JW, Iverson RL (1989) Distribution, abundance and productivity of seagrasses and macroalgae in Florida Bay. Bull Mar Sci 44:292-311

Zieman JC, Fourqurean JW, Frankovich TA (1999) Seagrass die-off in Florida Bay: long-term trends in abundance and growth of turtle grass Thalassia testudinium. Estuaries 22:460-470

Publisher's Note Springer Nature remains neutral with regard to jurisdictional claims in published maps and institutional affiliations. 